\title{
Variation in waterlogging response among ecotypes of Trifolium subterraneum ssp. yanninicum and their relationships with site of origin
}

Gereltsetseg Enkhbat ( $\square$ gereltsetseg.enkhbat@research.uwa.edu.au )

University of Western Australia https://orcid.org/0000-0002-9716-5252

Megan H. Ryan

The University of Western Australia, 35 Stirling Highway

Phillip G. H. Nichols

The University of Western Australia, 35 Stirling Highway

Kevin J. Foster

The University of Western Australia, 35 Stirling Highway

Yoshiaki Inukai

The University of Western Australia, 35 Stirling Highway

William Erskine

The University of Western Australia, 35 Stirling Highway

\section{Research Article}

Keywords: pasture legumes, genetic resources, seed size, cotyledon, eco-geographic variables, flowering time

Posted Date: September 16th, 2021

DOI: https://doi.org/10.21203/rs.3.rs-896192/v1

License: (c) (1) This work is licensed under a Creative Commons Attribution 4.0 International License. Read Full License 


\section{Abstract}

Background and Aims

In the annual pasture legume Trifolium subterraneum, ssp. yanninicum exhibits higher waterlogging tolerance than ssp. brachycalycinum and ssp. subterraneum. This study investigates waterlogging tolerance within ssp. yanninicum ecotypes and explores correlations with seedling phenotypic traits and site of origin eco-geographic variables.

Methods

Twenty eight diverse ssp. yanninicum ecotypes collected from the Mediterranean region and four cultivars were grown in a controlled environment glasshouse. After 14 days of growth seedling traits were measured. After 21 days of growth, free-drained (control) and waterlogged treatments were imposed for 28 days. Eco-geographic variables were generated from 'WorldClim' using collection site locations.

Results

Under waterlogging, shoot relative growth rate (RGR) ranged from $87-108 \%$ and root RGR ranged from $80-116 \%$ of controls. Waterlogging reduced shoot dry weight (DW) in four of 32 genotypes, while root DW was reduced in 13 genotypes. Leaf size was maintained, or even increased, under waterlogging in 31 genotypes. However, petiole length was more affected by waterlogging and has value as a waterlogging tolerance indicator. Waterlogging tolerance was not significantly correlated with seedling DW, flowering time or precipitation at the site of origin, while shoot growth under waterlogging had a positive correlation with summer temperatures at origin.

Conclusions

Genotypes of ssp. yanninicum tolerated transient waterlogging and greater tolerance was observed among ecotypes, rather than cultivars. An easy-to-measure indicator of tolerance was found in petiole length reduction. This study highlights untapped genotypic variability for breeders to improve the productivity and persistence of ssp. yanninicum under waterlogging.

\section{Introduction}

Soil waterlogging, a widespread abiotic stress worldwide, reduces crop production by $20-50 \%$ or more, depending on plant growth stage and duration and intensity of waterlogging (Bertholdsson 2013; Solaiman et al. 2007). Although Australia is one of the drier continents, soil subject to transient waterlogging covers a large area of farmland in southern Australia; estimated to be as much as 1 to 2 million ha in Western Australia (WA), and around 3.8 million ha in Victoria, as well as significant areas in other states (Malik et al. 2002; Setter and Waters 2003). The annual cost in terms of crop production lost in Australia has been estimated as AU\$90 million (Hamilton et al. 2000). While rainfall has decreased for the cropping regions of southern Australia over the past few decades and annual rainfall is projected to further decline, the intensity and frequency of heavy rainfall events are projected to increase with climate change (Chapman et al. 2012; Jarvis et al. 2010).

Annual plants in Mediterranean regions can experience waterlogging from excessive rainfall during the growing season (Real et al. 2008). In Australia, transient waterlogging occurs in poorly drained duplex soils (i.e. texture-contrast soils where a loamy clay dominates in the B horizon) which occupy 40 and $60 \%$ of agricultural land area in Victoria and WA, respectively (Tennant et al. 1992).

Soil waterlogging, also known soil flooding, occurs in the root-zone and is defined as the excess water saturation of soil pores affecting oxygen concentration and leading to hypoxia (low $\mathrm{O}_{2}$ concentration) and eventually to anoxia (absence of $\mathrm{O}_{2}$ ) (Armstrong 1980). Under waterlogging, the movement of gases, such as $\mathrm{O}_{2}$ and $\mathrm{CO}_{2}$, through water-filled soil pores and within roots into cells of plant organs dramatically decreases (gas diffusion is 10000 times slower in water than in air) (Bailey-Serres and Voesenek 2008; Colmer 2003; Voesenek and Sasidharan 2013). Oxygen deficiency inhibits aerobic respiration, resulting in a shortage of carbohydrates and energy that leads to an 'energy crisis' and disrupts photosynthesis and the uptake of nutrients from soil (Colmer and Greenway 2011; Pang et al. 2004). In addition, waterlogging reduces the availability in soil of some essential nutrients (e.g. N), but other ions such as manganese (Mn'+), iron $\left(\mathrm{Fe}^{2+}\right)$, sulphur $\left(\mathrm{S}^{2-}\right)$ and carboxylic acids can accumulate to toxic levels due to microbial anaerobic metabolism (Ponnamperuma 1984). Thus, soil waterlogging adversely affects plant growth and function and damage symptoms such as wilting, premature leaf senesce, growth cessation and premature death can result (Marschner 1995; Stoddard et al. 2006).

Subterranean clover (Trifolium subterraneum L., commonly known as subclover), originates from the Mediterranean region and Western Europe (Nichols et al. 1996) and is the most widespread pasture legume sown in southern Australia; a region with a Mediterranean-type climate and soils inherently low in nitrogen (N) (Nichols et al. 2013). Subclover has been sown over 29 million ha in southern Australia. Subclover has three subspecies used in agriculture in Australia: ssp. subterraneum; ssp. brachycalycinum; and ssp. yanninicum, each adapted to different soil types (Katznelson and Morley 1965).

Subspecies yanninicum was first commercialised for its high productivity on soils prone to flooding, particularly those with a high clay content (Francis and Devitt 1969; Reed et al. 1985). It is relatively infrequent in the wild, most often distributed in high rainfall coastal areas with mild winter temperatures (Ghamkhar et al. 2015). Among the Australian genetic resource collection of 8,812 subclover genotypes from 2,993 sites, ssp. yanninicum comprises only $2.2 \%$ of all genotypes (Nichols et al. 2013). Cultivars of ssp. yanninicum are important commercially and they are mostly grown in areas with high-medium annual rainfall (450-1200 mm), particularly on soils prone to waterlogging (Nichols et al. 2013). However, current cultivars of ssp. yanninicum were developed from a narrow genetic base (Nichols et al. 2013). There is, therefore, a need to explore the diversity among ecotypes and to identify traits for use in future

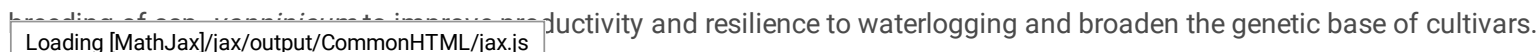


Several studies have examined waterlogging tolerance among these three subspecies of subclover and found ssp. yanninicum to generally exhibit a higher tolerance to waterlogging. Evidence for this comes from agronomic trials (Craig 1992; Peak and Morley 1973; Reed et al. 1985; Sandral et al. 2003), ecological surveys (Cocks 1994; Francis 1976; Katznelson and Morley 1965; Piano 1984) and glasshouse studies (Devitt and Francis 1972; Enkhbat et al. 2021b; Francis and Devitt 1969; Francis et al. 1974; Gibberd and Cocks 1997; Marshall and Millington 1967). However, genotypic variation in waterlogging tolerance among ecotypes of ssp. yanninicum has not been previously examined, nor its relationship with site of origin.

Exploration of waterlogging tolerance within species can yield significant benefit if tolerant genotypes are identified (Bailey-Serres and Voesenek 2008; Malik et al. 2015; Rogers et al. 2011). For example, Rogers et al. (2011) examined diversity in waterlogging tolerance among 23 genotypes of messina (Melilotus siculus (Turra) Vitman ex B.D. Jacks.), an annual forage legume with high tolerance to waterlogging, and identified several genotypes with greater shoot growth in a deoxygenated, stagnant treatment than in the aerated control. Similarly, Justin and Armstrong (1987) found that shoot growth in the majority of 91 wetland species was unaffected by, or increased under, waterlogging. Gibberd et al. (2001) explored waterlogging tolerance among 20 Trifolium species/subspecies and found nine genotypes without reduction in shoot growth under waterlogging, and two genotypes with increased growth, compared to drained controls. A review of shoot growth in wheat (Triticum aestivum L.) during waterlogging found that tolerant varieties consistently showed about twice the shoot growth of intolerant varieties (Setter and Waters 2003). Waterlogging tolerance has been found to vary among genotypes of many other crop and pasture legumes, including: barley (Hordeum vulgare L.) (Setter et al. 1999), chickpea (Cicer arietinum L.) (Palta et al. 2010), faba bean (Vicia faba L.) (Solaiman et al. 2007), lentil (Lens culinaris Medic.) and pea (Pisum sativum L.) (Malik et al. 2015), narrow leaf lupin (Lupinus angustifolius L.) (Davies et al. 2000) and lotus species (Lotus sp.) (Real et al. 2008).

Some phenotypic characteristics have a demonstrated relationship to waterlogging tolerance (Setter and Waters 2003). Under field conditions in a Mediterranean-type climate, where waterlogging can be experienced in late autumn/early winter through to early spring, long season wheat cultivars show a high yield advantage over short season cultivars (Gardner and Flood 1993; McDonald and Gardner 1987). Large-seeded pea and lentil genotypes demonstrated higher waterlogging tolerance than small-seeded genotypes, due to greater carbohydrate reserves and high early seedling vigour (Malik et al. 2015). Kabuli-chickpea, with larger seed and more vigorous early growth than desi chickpea, is better adapted to transient waterlogging (Palta et al. 2010; Siddique et al. 2000). Sultana et al. (2013) found large- (100 seed weigh $\geq 10 \mathrm{~g}$ ) and dark-seeded, long season genotypes of pigeon pea (Cajanus cajan L.) had greater waterlogging tolerance at the seedling stage than light-coloured, small-seeded (100 seed weigh $\leq 10 \mathrm{~g}$ ), short season genotypes. The advantage of the long season genotype reflects capacity for early sowing and establishment enabling them to avoid waterlogging during the intolerant stages of germination and emergence, as well as their flowering time being late enough to avoid spring waterlogging damage (Gardner and Flood 1993; McDonald and Gardner 1987),

The most common approach to define waterlogging tolerance is to assess factors related to the maintenance of growth rates and grain yield (e.g. shoot and root biomass, petiole and leaf growth) under waterlogging, relative to non-waterlogged conditions (Setter and Waters 2003). Morphological responses, such as shoot and root biomass production, formation of lateral roots and altered root distribution, are also crucial determinants of waterlogging tolerance. Root functioning and development in waterlogged soil is important to maintain stable plant growth (Yamauchi et al. 2018). For instance, an increase in the number of newly-formed adventitious roots (emerging above and along the soil surface during waterlogging) provides an internal path for oxygen movement (Yamauchi et al. 2018). Furthermore, waterlogging results in chlorophyll degradation in leaves due to nitrogen inhibition (Malik et al. 2015) and reduced uptake of nutrients (e.g. $\mathrm{K}^{+}$) into tissues (Colmer and Greenway 2011). Hence, examining waterlogging tolerance by assessing biomass production and chlorophyll content are recognized methodologies to identify genotypes with a higher tolerance to, and better performance under, waterlogged conditions.

Ecotypes from different geographical locations are a primary source of genetic diversity (Abdi et al. 2020; Ghamkhar et al. 2007). Measurements of their phenotypic traits provides an understanding of their adaptation, distribution and production potential (Hill 1996) and their prospective use in plant breeding and selection programs (Erskine et al. 1989; Piano et al. 1996). Enkhbat et al. (2021a) found large variation in morphological traits and flowering time corresponding to eco-geographic variables among 90 ecotypes of ssp. yanninicum in a common garden environment. Use of ssp. yanninicum from a diversity of origins, combined with the exploration of associations of stress tolerance with eco-geographic variables from their collection site, is an efficient approach to identify superior waterlogging tolerance. The overall objective of this study was, therefore, to investigate diversity for waterlogging tolerance in ssp. yanninicum. We tested three main hypotheses: (i) variation for waterlogging tolerance exists within ssp. yanninicum; (ii) such variability is related to phenotypic and growth trait differences; and (iii) ecotypic variability for waterlogging tolerance is related to eco-geographic variables at their sites of origin.

\section{Materials And Methods Plant materials}

Seeds of 32 genotypes of ssp. yanninicum were obtained from the Australian Pastures Genebank (APG) in 2019 and grown at the University of Western Australia Shenton Park Field Station to obtain fresh seed and for confirmation of subspecies identity (Enkhbat et al. 2021a). Genotypes of ssp. yanninicum consisted of: (i) 28 ecotypes (Treatment names: A-AB) collected from the wild in the Mediterranean basin, selected on the basis of diversity of geographic coordinates (longitude, latitude and altitude; referred to as passport data) and flowering time, as determined by (Enkhbat et al. 2021a); and (ii) four cultivars: Yarloop, Larisa, Meteora and Trikkala (Table 1). Included among these were four ecotypes (Treatments E, G, H and Q) with black-coloured seeds (as opposed to the usual amber/cream colour) identified by Enkhbat et al. (2021a). Cultivars Meteora and Larisa are ecotypes collected with passport data from Greece. However, cv. Yarloop is a naturalized strain from WA (Nichols et al. 1996; 2013; Oram 1989) and cv. Trikkala is derived from cross breeding and so neither have passport data (Nichols et al. 2013; PBR 2021). The geographic origins of the ecotypes is shown in Supplementary data Fig. S1. Additionally, the waterloggingsusceptible cultivars Antas (ssp. brachycalycinum) and Seaton Park (ssp. subterraneum) (Enkhbat et al. 2021b) and the waterlogging-tolerant T. michelianum cv. Frontier (Reed et al. 1985; Real et al. 2008; Rogers et al. 2009, 2011; Teakle et al. 2012; Striker et al. 2015; Kidd et al. 2020) were included as benchmarks for Loading [MathJax]/jax/output/CommonHTML/jax.js spectively. This gave a total of 35 genotypes (Table 1).

Page 3/21 
Table 1

List of 35 genotypes used in this study.

\begin{tabular}{|c|c|c|c|c|c|c|c|}
\hline \multirow[t]{2}{*}{ Genotype } & \multirow{2}{*}{$\begin{array}{l}\text { Treatment } \\
\text { Name }\end{array}$} & \multirow[t]{2}{*}{ Classification } & \multirow[t]{2}{*}{ Seed colour } & \multirow{2}{*}{$\begin{array}{l}\text { Country } \\
\text { of origin }\end{array}$} & \multicolumn{3}{|c|}{ Passport data } \\
\hline & & & & & Latitude & Longitude & Altitude \\
\hline ssp. yanninicum & & & & & $\left({ }^{\circ} \mathrm{N}\right)$ & $\left({ }^{\circ} \mathrm{E}\right)$ & (m a.s.l.) \\
\hline Yarloop & & Cultivar & Amber & Australia & & & \\
\hline Larisa & & Cultivar & Amber & Greece & 39.58 & 21.99 & 90 \\
\hline Meteora & & Cultivar & Amber & Greece & 39.58 & 21.96 & 100 \\
\hline Trikkala & & Cultivar & Amber & & & & \\
\hline CIZ001YANN-A & $A$ & Ecotype & Amber & Turkey & 38.64 & 27.28 & 25 \\
\hline CIZ011YANN-B & $\mathrm{B}$ & Ecotype & Amber & Turkey & 38.65 & 27.29 & 20 \\
\hline CPI 039314YB & $\mathrm{C}$ & Ecotype & Amber & Greece & 39.49 & 22.14 & 92 \\
\hline CPI 039315YC & $\mathrm{D}$ & Ecotype & Amber & Greece & 39.49 & 22.11 & 89 \\
\hline CPI 056904C & $\mathrm{E}$ & Ecotype & Black & Tunisia & 37.03 & 9.06 & 157 \\
\hline CPI 083937D & $\mathrm{F}$ & Ecotype & Amber & Greece & 38.98 & 21.27 & 725 \\
\hline CPI 083957Q & G & Ecotype & Black & Greece & 39.62 & 20.89 & 470 \\
\hline CPI 083967L & $\mathrm{H}$ & Ecotype & Black & Greece & 39.72 & 20.78 & 475 \\
\hline CPI 089797 & 1 & Ecotype & Amber & Italy & 40.49 & 8.51 & 310 \\
\hline CPI 089804E & $\mathrm{J}$ & Ecotype & Amber & Italy & 40.63 & 8.87 & 220 \\
\hline CPI 103925A & $\mathrm{K}$ & Ecotype & Amber & Spain & 37.4 & -6.22 & 50 \\
\hline CPI 103933 & $\mathrm{~L}$ & Ecotype & Amber & Spain & 37.63 & -6.65 & 360 \\
\hline DGG041-B & M & Ecotype & Amber & Greece & 39.68 & 19.8 & 90 \\
\hline DGG044WHITE-B & $\mathrm{N}$ & Ecotype & Amber & Greece & 39.65 & 19.82 & 80 \\
\hline DGG046-A & 0 & Ecotype & Amber & Greece & 39.67 & 19.78 & 75 \\
\hline DGG047-C & $\mathrm{P}$ & Ecotype & Amber & Greece & 39.67 & 19.78 & 75 \\
\hline DGG048-C & $\mathrm{Q}$ & Ecotype & Black & Greece & 39.66 & 19.75 & 130 \\
\hline EP042WHITE-C & $\mathrm{R}$ & Ecotype & Amber & Italy & 40.21 & 8.79 & 370 \\
\hline EP053WHITE-C & $S$ & Ecotype & Amber & Italy & 40.29 & 8.78 & 660 \\
\hline EP055WHITE-C & $\mathrm{T}$ & Ecotype & Amber & Italy & 40.44 & 8.71 & 420 \\
\hline EP059WHITE-C & $U$ & Ecotype & Amber & Italy & 40.46 & 8.73 & 425 \\
\hline EP060WHITE-A & $\mathrm{V}$ & Ecotype & Amber & Italy & 40.45 & 8.73 & 415 \\
\hline EP079WHITE-C & W & Ecotype & Amber & Italy & 40.91 & 9.45 & 38 \\
\hline EP082WHITE & $x$ & Ecotype & Amber & Italy & 40.9 & 9.49 & 25 \\
\hline EP084WHITE & $\mathrm{Y}$ & Ecotype & Amber & Italy & 40.81 & 9.66 & 20 \\
\hline EP091WHITE-B & Z & Ecotype & Amber & Italy & 40.52 & 9.62 & 75 \\
\hline LO0460 & AA & Ecotype & Amber & Spain & 38.85 & -5.6 & 398 \\
\hline L00751 & $A B$ & Ecotype & Amber & Spain & 39.1 & -5.33 & 370 \\
\hline \multicolumn{8}{|c|}{ ssp. brachycalycinum } \\
\hline Antas & & Cultivar & & & & & \\
\hline \multicolumn{8}{|l|}{ ssp. subterraneum } \\
\hline Seaton Park & & Cultivar & & & & & \\
\hline \multicolumn{8}{|l|}{ T. michelianum } \\
\hline Frontier & & Cultivar & & & & & \\
\hline
\end{tabular}




\section{Climatic data}

Climatic variables for collection sites of the ecotypes were extracted from the 'WorldClim' (Version 2) data base at 2.5 arc-minutes spatial resolution (Booth 2018; Ghamkhar et al. 2015; Hijmans et al. 2005; Trevor et al. 2014) and used to map a spatial model in the $R$ software package, as described in Enkhbat et al. (2021b). The 19 imported bioclimatic variables for all 30 sites are shown in Supplementary data Table S1, while a summary of the eco-geographic variables for 29 ecotypes is provided in Table 2. Ecotype E was the only ecotype collected from Tunisia (Supplementary data Fig. S1), a site with exceptionally high annual and winter precipitation (Table 1, Supplementary data Table S1), which greatly affected trait correlations with climatic variables and was, therefore, excluded from these analyses.

Table 2

Codes and definition of bioclimatic (BIOCLIM) variables and summary of eco-geographic (passport data and BIOCLIM) variables for $29 \mathrm{ssp}$. yanninicum ecotypes.

\begin{tabular}{|c|c|c|c|c|}
\hline \multirow[t]{2}{*}{ Definition of eco-geographic variables } & \multirow[t]{2}{*}{ Code } & \multicolumn{3}{|c|}{ Summary of variables } \\
\hline & & Min & Mean & Max \\
\hline Latitude $\left({ }^{\circ} \mathrm{N}\right)$ & & 37.4 & 39.7 & 40.9 \\
\hline Longitude $\left({ }^{\circ} \mathrm{E}\right)$ & & -6.7 & 13.1 & 27.3 \\
\hline Altitude (m) & & 20.0 & 230.8 & 725.0 \\
\hline Annual mean temperature $\left({ }^{\circ} \mathrm{C}\right)$ & $\mathrm{BIO1}$ & 11.9 & 15.2 & 18.0 \\
\hline Mean diurnal range $\left({ }^{\circ} \mathrm{C}\right.$, mean of monthly max-min temp) & $\mathrm{BIO} 2$ & 7.2 & 9.6 & 12.1 \\
\hline Isothermality $[(\mathrm{mdr} / \mathrm{amt}) \times 100]$ & $\mathrm{BIO} 3$ & 3.2 & 3.5 & 3.8 \\
\hline Temperature seasonality (standard deviation $\times 100$ ) & $\mathrm{BIO4}$ & 516.9 & 604.3 & 736.1 \\
\hline Maximum temperature of the warmest month $\left({ }^{\circ} \mathrm{C}\right)$ & $\mathrm{BIO5}$ & 27.3 & 30.5 & 35.3 \\
\hline Minimum temperature of the coldest month $\left({ }^{\circ} \mathrm{C}\right)$ & $\mathrm{BIO6}$ & -0.8 & 3.6 & 5.8 \\
\hline Temperature annual range $\left({ }^{\circ} \mathrm{C}\right)$ & $\mathrm{BIO7}$ & 21.8 & 27.0 & 33.7 \\
\hline Mean temperature of the wettest quarter $\left({ }^{\circ} \mathrm{C}\right)$ & $\mathrm{BIO8}$ & 5.2 & 10.1 & 13.2 \\
\hline Mean temperature of the driest quarter $\left({ }^{\circ} \mathrm{C}\right)$ & $\mathrm{BIO9}$ & 20.2 & 23.1 & 25.6 \\
\hline Mean temperature of the warmest quarter $\left({ }^{\circ} \mathrm{C}\right)$ & $\mathrm{BIO10}$ & 20.2 & 23.2 & 25.8 \\
\hline Mean temperature of the coldest quarter $\left({ }^{\circ} \mathrm{C}\right)$ & $\mathrm{BIO11}$ & 3.9 & 7.9 & 10.7 \\
\hline Annual precipitation (mm) & $\mathrm{BIO12}$ & 470.0 & 794.8 & 1182.0 \\
\hline Precipitation of the wettest month (mm) & $\mathrm{BIO13}$ & 61.0 & 126.4 & 198.0 \\
\hline Precipitation of the driest month (mm) & $\mathrm{BIO14}$ & 1.0 & 9.8 & 29.0 \\
\hline Precipitation seasonality (coefficient of variation) & $\mathrm{BIO15}$ & 41.0 & 56.5 & 76.0 \\
\hline Precipitation of the wettest quarter (mm) & $\mathrm{BIO16}$ & 164.0 & 342.7 & 554.0 \\
\hline Precipitation of the driest quarter (mm) & $\mathrm{BIO17}$ & 18.0 & 50.3 & 100.0 \\
\hline Precipitation of the warmest quarter (mm) & $\mathrm{BIO18}$ & 24.0 & 56.7 & 100.0 \\
\hline Precipitation of the coldest quarter (mm) & $\mathrm{BIO19}$ & 155.0 & 316.6 & 496.0 \\
\hline
\end{tabular}

\section{Plant growth}

The experiment was conducted in a naturally-lit glasshouse set at $20 / 15^{\circ} \mathrm{C}$ day/night at The University of Western Australia $\left(31^{\circ} 98^{\prime} \mathrm{S}, 115^{\circ} 50^{\prime} \mathrm{E}\right)$ from June to August 2020. Plants were grown in sterilised, free-draining plastic pots $(2.8 \mathrm{~L})$ containing $3.2 \mathrm{~kg}$ of steam-pasteurised soil which had been dried at $40{ }^{\circ} \mathrm{C}$. Weedstop ${ }^{\circledR}$ matting (Gale Pacific Limited) was placed in the bottom of each pot to prevent soil loss. The soil was a 1:1 mix of washed river sand and loam with a pH of $6.2\left(\mathrm{CaCl}_{2}\right)$. The water content $\left(\mathrm{w} \mathrm{w}^{-1}\right)$ at field capacity $(\mathrm{FC})$ was $15.5 \%$. Soil analyses, performed by CSBP Laboratories (Bibra Lake, Western Australia), are presented in Supplementary data Table S2. Two days prior to transplanting seeds, pots were watered to $60 \%$ of FC and all essential nutrients were applied ( $\mathrm{mg} \mathrm{kg}^{-1}$ soil $^{-1}$ ): P 20.5, K 88.7, S 34.2, Ca 41.0, Cl 72.5, Mg 3.95, Mn 3.26, Zn 2.05, Cu 0.51, B 0.12, Co 0.11, and Mo 0.08 according to Enkhbat et al. (2021b). These nutrients were reapplied in the same amounts at 14 days after sowing (DAS).

Seeds were germinated as described by Enkhbat et al. (2021b) with seed scarification followed by germination in Petri dishes (day of sowing) for $36-39$ hours in a darkened temperature-controlled room at $15^{\circ} \mathrm{C}$. Six seeds with newly-emerged radicles were transplanted (radicle placed downwards) to $10 \mathrm{~mm}$ depth and covered with soil. All pots were watered to $80 \% \mathrm{FC}$ with $40 \mathrm{~mL}$ of Rhizobium leguminosarum bv. trifolii strain WSM1325 (Group C) inoculum (mixture of $2.8 \mathrm{~g}$ of rhizobia in $1 \mathrm{~L}$ of water). Plants were grown for 21 days under free-draining conditions and were re-watered to $80 \% \mathrm{FC}$ every $2-3$ days. Pots were rearranged weekly to minimise positional effects. Plants were randomly thinned to three per pot at 14 days after sowing (DAS) with the thinned plants used to 


\section{Experimental design and treatments}

The experiment had a factorial randomised block design with two factors, two treatments and 35 genotypes in four replications. Each pot was an experimental unit. The two treatments consisted of: (i) a free-drained (control) treatment which was watered to $80 \%$ of FC for duration of the experiment; and (ii) a waterlogged treatment which commenced after 21 DAS and was maintained for 28 days. To impose the waterlogged treatment, pots were placed inside the same sized pots, sealed by plastic bags, and the water level was maintained $10 \mathrm{~mm}$ above the soil surface by daily watering.

\section{Harvests}

Two harvests were undertaken: initial harvest at 21 DAS and final harvest at 49 DAS. For each harvest, soil was gently washed with flowing water from the roots of all three plants in the pot onto a sieve (3 $\mathrm{mm}$ mesh).

\section{Measurements}

Seed and seedling phenotypic traits

Seed size Four replicates of 50 random seeds per genotype were counted using a Condator seed counter (Preuffer, Germany) and mean seed weight calculated.

Hypocotyl length and cotyledon size/weight Hypocotyl length and the size and weight of an individual cotyledon of each genotype were measured in 12 seedlings of each genotype (three seedlings from each pot) at 14 DAS. Intact seedlings were gently pulled from the soil. Hypocotyl length was measured by ruler from the junction of the cotyledons until the joint with the radicle (Supplementary data Fig. S2). Cotyledon size was estimated by comparison with the photographic plates and conversion formulae in Williams et al. (1964). Cotyledon weight was determined by cutting cotyledons at the junction with the shoot and oven-drying at $60^{\circ} \mathrm{C}$ for three days before weighing.

Leaf size and petiole length At the initial harvest (21 DAS), leaf size (three leaflets combined) and petiole length of the first trifoliate leaf in each pot were measured for each ssp. yanninicum genotype. Leaf size was estimated by comparison with the photographic leaf size standards for subclover of Williams et al. (1964) and using their conversation formulae. Petiole length of the same leaves was measured by ruler.

Days to first flowering Data for days to first flowering (DFF, the number of days from sowing to the appearance of the first open flower) for the 32 genotypes of ssp. yanninicum are from Enkhbat et al. (2021a).

Traits under waterlogging

Shoot and root RGRs Harvested plants were separated into shoots and roots at both harvests and oven-dried at $60{ }^{\circ} \mathrm{C}$ for four days and weighed. Shoot and root relative growth rates (RGR) were calculated using the standard equation of Hunt (1982):

$\mathrm{RGR}=(\operatorname{lnDW} 2-\ln D W 1) /(\mathrm{t} 2-\mathrm{t} 1)$

where: DW2 = dry weight at final harvest (g); DW1 = dry weight at initial harvest (g), and t2-t1 = number of days between harvests (28 days).

Leaf size and petiole length At the final harvest (49 DAS), leaf size and petiole length of the fourth trifoliate leaf of each plant were measured using the same methods as the initial harvest for all subclover genotypes. Because T. michelianum has a different leaf shape to subclover, leaf size of cv. Frontier was measured using a portable leaf area meter (LI 3000; LI-COR Biosciences, Lincoln, USA).

Chlorophyll content At 44 DAS, relative changes in chlorophyll content (SPAD unit) of the youngest fully-opened leaf of all plants were measured by a chlorophyll meter (Konica Minolta SPAD-502 Plus, Osaka, Japan).

Surface root proliferation Relative differences in the amount of surface roots found growing above the soil surface under waterlogged conditions were assessed at 49 DAS (final harvest) for each genotype using a 1-10 visual rating scale, where 1 was the lowest root density and 10 was the highest density.

\section{Statistical analyses}

Data are graphed as mean \pm standard error $( \pm$ SE) using SigmaPlot 14 (Systat Software, Inc.). Genotypes were ordered in the graphs based on their tolerance, defined as maintenance of shoot growths relative to controls, and this order was consistent in all other graphs. Among genotypes of ssp. yanninicum data were analysed by two-way ANOVA, with genotype and treatment as main factors, in $R$ software (version 3.6.3). Least significant difference (LSD) Fisher's protected tests were used to test treatment effects for each genotype.

One-way ANOVA was used to compare genotypic variation of ssp. yanninicum mean seed weight and traits measured at 14 DAS (cotyledon size/weight and hypocotyl length) and at 21 DAS (leaf size and petiole length of the first trifoliate leaf, shoot and root DWs). Broad-sense heritability ( $\mathrm{H}^{2}$ ) was also estimated for these traits across the genotypes of ssp. yanninicum, according to Falconer (1989). It was also used to assess genotypic variation for surface root growth under waterlogging in all genotypes.

Pearson correlation coefficients and their levels of significance were calculated between all traits measured at 14 and 21 DAS and traits under waterlogged conditions at 28 days after treatment (DAT) for genotypes of ssp. yanninicum. They were also calculated between plant traits and eco-geographic (passport data and BIOCLIM) variables of collection sites. 


\section{Results}

Variation for phenotypic traits

Significant genotype differences $(0.01<P<0.001)$ were found among the $32 \mathrm{ssp}$. yanninicum genotypes for all seed and seedling traits $(T a b l e ~ 3)$. The mean values for these traits are shown in Supplementary data Table S3.

Table 3

The mean, range, significance level $\left(P\right.$-value) and broad-sense heritability $\left(\mathrm{H}^{2}\right)$ among genotypes of phenotypic seedling traits prior to imposition of treatments

\begin{tabular}{|c|c|c|c|c|c|}
\hline Trait & Mean & Minimum & Maximum & $P$-value & $H^{2}(\%)$ \\
\hline Mean seed weight (mg) & 8.61 & 5.60 & 13.60 & $\star \star \star *$ & 94 \\
\hline \multicolumn{6}{|l|}{ At 14 DAS } \\
\hline Cotyledon size $\left(\mathrm{cm}^{2}\right)$ & 0.45 & 0.34 & 0.57 & $\star \star \star *$ & 47 \\
\hline Cotyledon DW (mg) & 1.71 & 1.12 & 2.75 & $\star \star *$ & 66 \\
\hline Hypocotyl length (mm) & 9.13 & 6.75 & 13.29 & $\star * *$ & 58 \\
\hline \multicolumn{6}{|l|}{ At 21 DAS } \\
\hline Leaf size $\left(\mathrm{cm}^{2}\right)$ & 2.53 & 1.69 & 3.60 & $\star \star *$ & 64 \\
\hline Petiole length (cm) & 3.62 & 1.92 & 5.70 & $\star \star \star *$ & 71 \\
\hline Shoot DW (g) & 0.07 & 0.05 & 0.11 & $\star \star *$ & 56 \\
\hline Root DW (g) & 0.04 & 0.02 & 0.05 & ** & 24 \\
\hline \multicolumn{6}{|l|}{ Days to flowering } \\
\hline DFF (days) & 123 & 100 & 149 & $\star \star \star$ & 94 \\
\hline \multicolumn{6}{|c|}{$\star P \leq 0.05, * \star P \leq 0.01, * \star \star P \leq 0.001$} \\
\hline
\end{tabular}

Plant growth under waterlogging

Waterlogging tolerance was assessed as the maintenance of plant growth under waterlogged conditions, relative to plants grown in free-draining conditions (control).

\section{Shoot and root $R G R$}

There was a significant treatment $\times$ genotype interaction for root RGR $(P<0.001)$ but not for shoot RGR at 28 DAT (Fig. 1). Shoot RGRs under waterlogging ranged from $87-108 \%$ of controls, while root RGRs ranged from $80-116 \%$ of controls (Supplementary data Table S4).

Waterlogging reduced shoot RGRs in four out of $32 \mathrm{ssp}$. yanninicum genotypes and root RGRs in 13 genotypes, compared to their controls (Fig. 1; Supplementary data Table S4). Among the genotypes of ssp. yanninicum, ecotype D showed a superior tolerance to waterlogging with both shoot $(P<0.05)$ and root $(P<0.01)$ RGRs were significantly higher than its controls $(105 \%$ and $113 \%$ of controls, respectively). In contrast, both shoot and root RGRs of $\mathrm{cv}$. Seaton Park ssp. subterraneum ( $82 \%$ and $73 \%$ of controls, respectively) and cv. Antas ssp. brachycalycinum ( $87 \%$ and $85 \%$ ) were severely decreased by waterlogging compared to their respective controls (Fig. 1; Supplementary data Table S4). For cv. Frontier T. michelianum both shoot and root DWs were unaffected by waterlogging and did not differ from control treatment ( $99 \%$ and $97 \%$ of controls, respectively).

\section{Shoot and root DW}

There was a significant treatment $\times$ genotype interaction for both shoot $(P<0.05$; Fig. 2a) and root $(P<0.001$, Fig. 2b) DWs among the 32 ssp. yanninicum genotypes at 28 DAT. Marked variation was observed under waterlogging for both shoot (66-120\% of controls) and root (58-137\%) DWs (Supplementary data Table S4).

Waterlogging reduced shoot DWs in only four out of 32 genotypes compared to controls, but reduced root DWs in 13 genotypes. Among yanninicum genotypes, ecotype $\mathrm{D}$ showed superior tolerance to waterlogging with both shoot $(P<0.05)$ and root $(P<0.01)$ DWs significantly higher than its controls $(115 \%$ and $133 \%$ of controls, respectively) (Fig. 2). In contrast, both shoot and root DWs of cv. Seaton Park ssp. subterraneum (58\% and $49 \%$ of controls, respectively) and cv. Antas ssp. brachycalycinum (64\% and 68\%) were severely decreased, compared to their respective controls. For cv. Frontier T. michelianum, both shoot and root DWs were unaffected by waterlogging and did not differ from control treatment ( $92 \%$ and $87 \%$ of controls, respectively).

Leaf size and petiole length 
For leaf size, there was a significant treatment $\times$ genotype interaction $(P<0.01$; Fig. 3a) among genotypes of ssp. yanninicum. Leaf size under waterlogging ranged from $76-130 \%$ of controls (Supplementary data Table S4). Waterlogging reduced leaf size in only one ecotype, compared to its control ( $P<0.01$ ) (Fig. 3a; Supplementary data Table S4). In contrast, five ecotypes had significantly larger leaves than their respective controls. Leaf sizes for both cv. Seaton Park ssp. subterraneum (49\%) and cv. Antas ssp. brachycalycinum (67\%) were severely reduced by waterlogging, whereas leaf size in cv. Frontier $T$. michelianum (94\%) was unchanged by the waterlogging treatment.

For petiole length, there was a significant treatment $\times$ genotype interaction $(P<0.001 ;$ Fig. $3 \mathrm{~b})$ among genotypes of ssp. yanninicum. Petiole length ranged from $63-105 \%$ of controls (Supplementary data Table S4). Waterlogging reduced petiole length in 13 out of 32 genotypes compared to controls. Petiole length in the remaining 19 genotypes was unaffected by waterlogging and did not differ from control treatment. Petiole lengths for cv. Seaton Park ssp. subterraneum (58\%), cv. Antas ssp. brachycalycinum (77\%) and cv. Frontier T. michelianum (77\%) were significantly reduced compared to their respective controls.

\section{Surface root proliferation}

There was a significant genotype difference $(P<0.001)$ for surface root density under waterlogging (Fig. 4; Supplementary data Table S4). At 28 DAT under waterlogging, surface roots were observed in all genotypes, irrespective of their tolerance. Notably, the highest surface roots occurred in two of the blackseeded ecotypes: $\mathrm{H}$ (score 10.0) and $\mathrm{G}$ (score 9.4). The density of surface roots in the other genotypes ranged from scores of 1-7.

\section{Chlorophyll content}

There was a significant treatment $\times$ genotype interaction $(P<0.001$; Fig. 5$)$ for leaf chlorophyll content among genotypes of ssp. yanninicum. Leaf chlorophyll content under waterlogging was reduced significantly $(0.01<P<0.001)$ for all genotypes compared to their controls (Supplementary data Table 54 ).

Relationships between waterlogging tolerance with phenotypic traits

For ssp. yanninicum, correlation analyses were conducted for all measured traits (Table 4). Among all possible correlations, of most interest was the identification of traits that correlated with growth (shoot and root RGRs) under waterlogging. Second in importance were traits that correlated with leaf size and petiole length. 
Table 4

Pearson correlation coefficients $(r)$ and significance for traits among 32 ssp. yanninicum genotypes (4 cultivars and 28 ecotypes). Mean seed weight of 50 se was measured at the day of sowing. Other traits were measured at 14 and 21 days after sowing (DAS) prior to waterlogging being imposed and at 28 days a treatment (DAT) under waterlogging. Waterlogging treatment (water level was kept $10 \mathrm{~mm}$ above the soil surface) was imposed after 21 days of growth.

\begin{tabular}{|c|c|c|c|c|c|c|c|c|c|c|c|c|c|c|c|}
\hline & Traits & 1 & 2 & 3 & 4 & 5 & 6 & 7 & 8 & 9 & 10 & 11 & 12 & 13 & 14 \\
\hline & $\begin{array}{l}\text { At } 28 \text { DAT } \\
\text { (waterlogged } \\
\text { treatment) }\end{array}$ & & & & & & & & & & & & & & \\
\hline 1 & $\begin{array}{l}\text { Shoot RGR } \\
\text { (\% of } \\
\text { control) }\end{array}$ & & & & & & & & & & & & & & \\
\hline 2 & $\begin{array}{l}\text { Root RGR (\% } \\
\text { of control) }\end{array}$ & $0.86^{\star * *}$ & & & & & & & & & & & & & \\
\hline 3 & $\begin{array}{l}\text { Leaf size (\% } \\
\text { of control) }\end{array}$ & $0.55^{\star \star}$ & n.s. & & & & & & & & & & & & \\
\hline 4 & $\begin{array}{l}\text { Petiole } \\
\text { length (\% of } \\
\text { control) }\end{array}$ & $0.59 * * \star$ & $0.57^{\star \star \star}$ & $0.49 * *$ & & & & & & & & & & & \\
\hline 5 & $\begin{array}{l}\text { Chlorophyll } \\
\text { content (\% } \\
\text { of control) }\end{array}$ & n.s. & n.s. & n.s. & n.s. & & & & & & & & & & \\
\hline \multirow[t]{2}{*}{6} & $\begin{array}{l}\text { Surface } \\
\text { roots }(1-10 \\
\text { score) }\end{array}$ & n.s. & n.s. & n.s. & n.s. & n.s. & & & & & & & & & \\
\hline & $\begin{array}{l}\text { Flowering } \\
\text { and seed } \\
\text { weight }\end{array}$ & & & & & & & & & & & & & & \\
\hline 7 & DFF (days) & n.s. & n.s. & n.s. & n.s. & n.s. & n.s. & & & & & & & & \\
\hline \multirow[t]{2}{*}{8} & $\begin{array}{l}\text { Mean seed } \\
\text { weight (mg) }\end{array}$ & n.s. & n.s. & n.s. & $-0.38 *$ & n.s. & n.s. & n.s. & & & & & & & \\
\hline & At $14 D A S$ & & & & & & & & & & & & & & \\
\hline 9 & $\begin{array}{l}\text { Cotyledon } \\
\text { size }\left(\mathrm{cm}^{2}\right)\end{array}$ & $-0.40 *$ & n.s. & $-0.53^{\star *}$ & $-0.52^{\star \star}$ & n.s. & n.s. & n.s. & $0.67^{\star \star \star}$ & & & & & & \\
\hline 10 & $\begin{array}{l}\text { Cotyledon } \\
\text { DW (mg) }\end{array}$ & n.s. & n.s. & $-0.39 *$ & $-0.45^{\star \star}$ & n.s. & n.s. & n.s. & $0.92^{\star \star \star}$ & $0.76^{\star \star \star}$ & & & & & \\
\hline \multirow[t]{2}{*}{11} & $\begin{array}{l}\text { Hypocotyl } \\
\text { length (mm) }\end{array}$ & n.s. & n.s. & n.s. & $-0.39 *$ & n.s. & n.s. & n.s. & n.s. & $0.41^{*}$ & $0.35^{\star}$ & & & & \\
\hline & At 21 DAS & & & & & & & & & & & & & & \\
\hline 12 & $\begin{array}{l}\text { Leaf size } \\
\left(\mathrm{cm}^{2}\right)\end{array}$ & n.s. & n.s. & $-0.59 * * *$ & -0.53 ** & n.s. & n.s. & n.s. & $0.63^{\star \star \star}$ & $0.76^{\star \star \star}$ & $0.69 * \star \star$ & $0.37 *$ & & & \\
\hline 13 & $\begin{array}{l}\text { Petiole } \\
\text { length (cm) }\end{array}$ & $-0.38^{*}$ & $-0.35^{\star}$ & -0.48 ** & n.s. & n.s. & 0.52 ** & n.s. & $0.44^{*}$ & $0.55^{\star *}$ & $0.49 * \star$ & n.s. & $0.52^{\star \star}$ & & \\
\hline 14 & $\begin{array}{l}\text { Shoot DW } \\
\text { (g) }\end{array}$ & n.s. & n.s. & n.s. & $-0.36^{\star}$ & n.s. & n.s. & n.s. & $0.92^{\star \star \star}$ & $0.73^{\star \star \star}$ & $0.90^{\star \star \star *}$ & n.s. & $0.68^{\star \star \star}$ & $0.63^{* \star *}$ & \\
\hline 15 & Root DW (g) & n.s. & n.s. & n.s. & n.s. & n.s. & n.s. & n.s. & $0.62^{\star \star \star}$ & $0.41^{\star}$ & $0.40 *$ & n.s. & $0.39 *$ & $0.43^{*}$ & 0.66 \\
\hline
\end{tabular}

Strength of correlation is shown by increasing intensity of green for positive and by increasing intensity of blue for negative.

Days to first flowering (DFF, the number of days from sowing to first open flower) is from Enkhbat et al. (2021a), recorded from an early May sowing at Shent Park, Western Australia $\left(31^{\circ} 57^{\prime} \mathrm{S}, 115^{\circ} 5^{\prime} \mathrm{E}\right)$.

Strong positive correlations were found between shoot and root RGRs under waterlogging. Under waterlogging, petiole length had strong positive correlations to both shoot and root RGRs, while leaf size had a high positive correlation with only shoot RGR. Surprisingly, neither chlorophyll content nor surface root proliferation were significantly correlated to shoot and root RGRs under waterlogging.

Seedling phenotypic traits under free-draining conditions had negative correlations with traits measured under waterlogging (28 DAT). In other words, genotypes of ssp. yanninicum with larger seeds (bigger cotyledons) and vigorous seedling biomass under free-draining condition with larger leaves and longer petioles (21 DAS) showed a low RGR under waterlogging. DFF did not correlate significantly with any other trait (Table 4).

Relationships of variation for waterlogging tolerance with eco-geographic variables for ssp. yanninicum ecotypes 
Pearson correlation coefficients between measured traits and eco-geographic variables are shown in Table 5 for passport data and eight standard BIOCLIM precipitation variables (BIO12-BIO19) and in Table 6 for 11 standard BIOCLIM temperature variables (BIO1-BIO11). A total of 29 ecotypes of ssp. yanninicum were used to examine correlations of plant response to waterlogging with eco-geographic variables from their collection sites. Transient waterlogging is strongly affected by much localized topography while heat or drought stress damage can be over quite a wide geographic area (Khazaei et al. 2013). For this reason the broad geographic/ecological approach offered by the analysis of collection site agro-variables is less useful in the prediction/identification of transient waterlogging than heat and drought stress.

Table 5

Pearson correlation coefficients $(r)$ and significance between mean values of traits and 11 eco-geographic variables (passport data and BIOCLIM precipitation variables BIO12-BIO19) for $29 \mathrm{ssp}$. yanninicum ecotypes with known passport data. Mean seed weight of 50 seeds was measured prior sowing. Other traits were measured at 14 and 21 days after sowing (DAS) and at 28 days after treatment (DAT) under waterlogged conditions. The waterlogging treatment (water level was kept $10 \mathrm{~mm}$ above the soil surface) was imposed after 21 days of

\begin{tabular}{|c|c|c|c|c|c|c|c|c|c|c|c|}
\hline Traits & Lat & Lon & Alt & BI012 & BI013 & BI014 & BI015 & BIO16 & BI017 & BI018 & BI019 \\
\hline & $\left({ }^{\circ} \mathrm{N}\right)$ & $\left({ }^{\circ} \mathrm{E}\right)$ & $(\mathrm{m})$ & $(\mathrm{mm})$ & $(\mathrm{mm})$ & $(\mathrm{mm})$ & & $(\mathrm{mm})$ & $(\mathrm{mm})$ & $(\mathrm{mm})$ & $(\mathrm{mm})$ \\
\hline \multicolumn{12}{|l|}{ At $28 D A T$} \\
\hline Shoot RGR (\% of control) & n.s. & n.s. & n.s. & n.s. & n.s. & n.s. & n.s. & n.s. & n.s. & n.s. & n.s. \\
\hline Root RGR (\% of control) & n.s. & n.s. & n.s. & n.s. & n.s. & n.s. & n.s. & n.s. & n.s. & n.s. & n.s. \\
\hline Leaf size (\% of control) & n.s. & n.s. & n.s. & $-0.41^{*}$ & $-0.41^{\star}$ & n.s. & n.s. & $-0.41^{\star}$ & n.s. & n.s. & $-0.43^{\star}$ \\
\hline Petiole length (\% of control) & n.s. & n.s. & n.s. & n.s. & n.s. & n.s. & n.s. & n.s. & n.s. & n.s. & n.s. \\
\hline Chlorophyll content (\% of control) & n.s. & n.s. & n.s. & n.s. & n.s. & $-0.43^{*}$ & n.s. & n.s. & $-0.43^{\star}$ & $-0.43^{\star}$ & n.s. \\
\hline Surface roots ( $1-10$ score) & n.s. & n.s. & n.s. & n.s. & n.s. & $0.59 * \star$ & n.s. & n.s. & $0.46^{*}$ & n.s. & n.s. \\
\hline \multicolumn{12}{|l|}{ Seed weight } \\
\hline Mean seed weight (mg) & n.s. & n.s. & n.s. & $0.56^{\star \star}$ & $0.57^{\star *}$ & n.s. & n.s. & $0.56^{\star \star}$ & n.s. & n.s. & $0.54^{\star *}$ \\
\hline \multicolumn{12}{|l|}{ At 14 DAS } \\
\hline Cotyledon size $\left(\mathrm{cm}^{2}\right)$ & n.s. & n.s. & n.s. & $0.54^{\star \star}$ & $0.50 \star \star$ & n.s. & n.s. & $0.50 * \star$ & n.s. & n.s. & $0.47^{\star}$ \\
\hline Cotyledon DW (mg) & n.s. & n.s. & n.s. & $0.57^{\star \star}$ & $0.55^{\star \star}$ & n.s. & n.s. & $0.55^{\star \star}$ & n.s. & n.s. & $0.52^{\star *}$ \\
\hline Hypocotyl length (mm) & n.s. & n.s. & n.s. & n.s. & n.s. & n.s. & n.s. & n.s. & n.s. & n.s. & n.s. \\
\hline \multicolumn{12}{|l|}{ At $21 D A S$} \\
\hline Leaf size $\left(\mathrm{cm}^{2}\right)$ & n.s. & n.s. & n.s. & $0.58^{\star \star \star}$ & $0.55^{\star \star}$ & n.s. & n.s. & $0.54^{\star \star}$ & n.s. & n.s. & $0.54^{\star \star}$ \\
\hline Petiole length (cm) & n.s. & $0.55^{\star \star}$ & n.s. & $0.57^{\star \star}$ & $0.52^{\star \star}$ & $0.59 \star \star \star$ & n.s. & $0.52^{\star \star}$ & $0.54^{\star *}$ & $0.49 * \star$ & $0.52^{\star *}$ \\
\hline Shoot DW (g) & n.s. & n.s. & n.s. & $0.59 \star \star \star$ & $0.57^{\star *}$ & n.s. & n.s. & $0.57 * \star$ & n.s. & n.s. & $0.54 * *$ \\
\hline Root DW (g) & n.s. & n.s. & n.s. & n.s. & n.s. & n.s. & n.s. & n.s. & n.s. & n.s. & n.s. \\
\hline n.s. not significant, ${ }^{\star} P \leq 0.05, * *$ & 01 & $\leq 0$ & & & & & & & & & \\
\hline
\end{tabular}


Table 6

Pearson correlation coefficients $(r)$ and significance between mean values of traits and 11 eco-geographic variables (BIOCLIM temperature variables BI01-BI011) for 29 ssp. yanninicum with known passport data. Mean seed weight of 50 seeds was measured at the day of sowing. Other traits were measured at 14 and 21 days after sowing (DAS) and at 28 days after treatment (DAT) under waterlogged condition. Waterlogging treatment (water level was kept $10 \mathrm{~mm}$ above the soil surface) was imposed after 21 days of growth. Codes and definitions of BIOCLIM variables are in Supplementary data Table 2.

\begin{tabular}{|c|c|c|c|c|c|c|c|c|c|c|c|}
\hline Traits & $\mathrm{BIO1}$ & $\mathrm{BIO} 2$ & $\mathrm{BIO3}$ & $\mathrm{BIO4}$ & BIO5 & $\mathrm{BIO6}$ & $\mathrm{BIO7}$ & $\mathrm{BIO8}$ & BI09 & $\mathrm{BIO10}$ & BI011 \\
\hline & $\left({ }^{\circ} \mathrm{C}\right)$ & $\left({ }^{\circ} \mathrm{C}\right)$ & & & $\left({ }^{\circ} \mathrm{C}\right)$ & $\left({ }^{\circ} \mathrm{C}\right)$ & $\left({ }^{\circ} \mathrm{C}\right)$ & $\left({ }^{\circ} \mathrm{C}\right)$ & $\left({ }^{\circ} \mathrm{C}\right)$ & $\left({ }^{\circ} \mathrm{C}\right)$ & $\left({ }^{\circ} \mathrm{C}\right)$ \\
\hline \multicolumn{12}{|l|}{ At $28 D A T$} \\
\hline Shoot RGR (\% of control) & n.s. & n.s. & n.s. & n.s. & $0.42^{\star}$ & n.s. & n.s. & n.s. & $0.43^{*}$ & $0.44^{*}$ & n.s. \\
\hline Root RGR (\% of control) & n.s. & n.s. & n.s. & n.s. & $0.39 *$ & n.s. & n.s. & n.s. & n.s. & n.s. & n.s. \\
\hline Leaf size (\% of control) & n.s. & n.s. & n.s. & n.s. & n.s. & n.s. & n.s. & n.s. & n.s. & n.s. & n.s. \\
\hline Petiole length (\% of control) & n.s. & n.s. & n.s. & n.s. & n.s. & n.s. & n.s. & n.s. & n.s. & n.s. & n.s. \\
\hline Chlorophyll content (\% of control) & n.s. & n.s. & n.s. & n.s. & n.s. & n.s. & n.s. & n.s. & n.s. & n.s. & n.s. \\
\hline Surface roots (1-10 score) & $-0.45^{\star}$ & n.s. & n.s. & n.s. & n.s. & $-0.46^{\star}$ & n.s. & $-0.57 * \star$ & n.s. & n.s. & $-0.47 *$ \\
\hline \multicolumn{12}{|l|}{ Seed weight } \\
\hline Mean seed weight (mg) & n.s. & n.s. & n.s. & n.s. & n.s. & n.s. & n.s. & n.s. & n.s. & n.s. & n.s. \\
\hline \multicolumn{12}{|l|}{ At 14 DAS } \\
\hline Cotyledon size $\left(\mathrm{cm}^{2}\right)$ & n.s. & n.s. & n.s. & n.s. & n.s. & n.s. & n.s. & n.s. & n.s. & n.s. & n.s. \\
\hline Cotyledon DW (mg) & n.s. & n.s. & n.s. & n.s. & n.s. & n.s. & n.s. & n.s. & n.s. & n.s. & n.s. \\
\hline Hypocotyl length (mm) & n.s. & n.s. & n.s. & n.s. & n.s. & n.s. & n.s. & n.s. & n.s. & n.s. & n.s. \\
\hline \multicolumn{12}{|l|}{ At 21 DAS } \\
\hline Leaf size $\left(\mathrm{cm}^{2}\right)$ & n.s. & n.s. & n.s. & n.s. & n.s. & n.s. & n.s. & n.s. & n.s. & n.s. & n.s. \\
\hline Petiole length (cm) & n.s. & n.s. & n.s. & n.s. & n.s. & n.s. & n.s. & n.s. & $-0.39 *$ & $-0.39 *$ & n.s. \\
\hline Shoot DW (g) & n.s. & n.s. & n.s. & n.s. & n.s. & n.s. & n.s. & n.s. & n.s. & n.s. & n.s. \\
\hline Root DW (g) & n.s. & n.s. & n.s. & n.s. & n.s. & n.s. & n.s. & n.s. & n.s. & n.s. & n.s. \\
\hline \multicolumn{12}{|c|}{ n.s. not significant, ${ }^{\star} P \leq 0.05,{ }^{\star *} P \leq 0.01,{ }^{\star * \star} P \leq 0.001$. } \\
\hline
\end{tabular}

Geographic coordinates did not correlate significantly with any traits measured both under waterlogging and under control treatments and seed weight (Tables 5 and 6). Only petiole length at 21 DAS had a strong positive correlation with longitude, showing genotypes from eastern end of the botanical range tended to have long petioles at seedling stage.

Precipitation variables at the site of origin did not correlate with shoot or root RGRs under waterlogging except leaf size (Table 5). Smaller leaves under waterlogging (at 28 DAT) had to be associated with higher annual precipitation (BIO12) and winter precipitation (BIO13, BIO16 and BIO19). In contrast, annual (BI012) and winter precipitation (BI013, BIO16 and BI019) showed positive correlations with several traits measured under free-draining conditions. Notably, growth of petioles at 21 DAS positively correlated with the majority of precipitation variables including annual, summer and winter precipitation (BIO12, BIO13, BIO14, BIO16, BIO17, BIO18 and BIO19) (Table 5).

Temperature variables at site of origin correlated with RGR under waterlogging (Table 6). Notably, warmer temperatures at site of origin correlated with increased growth under waterlogging of ssp. yanninicum, showing positive correlations between shoot/root RGRs and maximum temperature of the warmest month (BIO5), mean temperature of the driest (BI09) and warmest quarter (BI010). Surface root proliferation under waterlogging negatively correlated with winter temperature variables (BIO6, $\mathrm{BIO} 8$ and $\mathrm{BIO11})$.

\section{Discussion}

This study evaluated variation for waterlogging tolerance among a diverse range of ssp. yanninicum genotypes by assessing the maintenance of plant growth (shoot and root RGRs) relative to free-drained conditions. Variation for waterlogging tolerance was evident, with several ecotypes displaying high tolerance with equivalent or greater growth under waterlogging than in free-drained controls. It is noteworthy that the highest tolerance to waterlogging was observed among wild ecotypes rather than commercialized cultivars. The variation in waterlogging tolerance among ssp. yanninicum and associated traits that contributed to waterlogging tolerance or explained sensitivity to waterlogging are now discussed in more detail.

Plant growth under waterlogging 
Root growth was more affected by waterlogging than shoot growth in ssp. yanninicum, supporting the assertions of Colmer and Voesenek (2009), Herzog et al. (2016), Nakai et al. (2009) and Striker (2012a) that soil waterlogging causes a direct effect on the root system reducing its growth and function (BaileySerres and Voesenek 2008; Colmer and Voesenek 2009; Malik et al. 2002). A high positive correlation between root and shoot growth rate under waterlogging in the present study demonstrated the primary role of root systems to waterlogging tolerance (Armstrong et al. 1983; Gibberd and Cocks 1997; Gibberd et al. 2001; Rogers and West 1993; Yamauchi et al. 2018). Moreover, all genotypes developed surface roots in response to waterlogging, in a similar finding to Francis and Devitt (1969) and Enkhbat et al. (2021b). The ability of plants to alter their root distribution patterns along and above the soil surface is a common response to waterlogging to obtain oxygen (Voesenek et al. 1999). Root proliferation near to soil surface in the present study supported findings of Mano et al. (2006) for maize (Zea mays L.), Erskine et al. (1994) and Solaiman et al. (2007) for lentil, Malik et al. (2015) for lentil, grasspea (Lathyrus sativa L.) and pea, and Cannell and Belford (1980) for canola (Brassica napus L.).

Leaf size and petiole length

Leaf growth among genotypes of ssp. yanninicum was the least affected by waterlogging, while petiole growth was more sensitive. Francis and Devitt (1969) also found no reduction in leaf size among 25 genotypes of ssp. yanninicum under waterlogging. Strong positive correlations between leaf size and waterlogging tolerance were also found in the three subspecies of subclover (Enkhbat et al. 2021b) and in Brassica species (Ashraf and Mehmood 1990). This could be explained as ssp. yanninicum invests more assimilates to increase leaf biomass proportion rather than petiole growth in response to soil waterlogging. A high proportion of leaf biomass and larger leaves can provide increased uptake of atmospheric oxygen and greater exchange of gases (Colmer 2003; Striker et al. 2005; Striker and Colmer 2017). Additionally, reduction in petiole length under waterlogging can be used as a visual indicator of the strength of waterlogging stress in ssp. yanninicum.

\section{Chlorophyll content}

A significant reduction in chlorophyll content, with characteristic yellowing of the leaves, was observed in all genotypes of ssp. yanninicum as found among subclover subspecies (Enkhbat et al. 2021b), Brassica species (Ashraf and Mehmood 1990), Salix species (Talbot et al. 1987) and barley (Pang et al. 2004). Leaf chlorophyll degradation is a common symptom of waterlogging stress (Smethurst and Shabala 2003). Huang Bingru et al. (1994); Malik et al. (2002); Striker and Colmer (2016) have all reported reductions in leaf chlorophyll content caused by inhibition of N, and damaged photosynthetic apparatus, especially when waterlogging extends for several weeks.

Relationships of variation for waterlogging tolerance with phenotypic traits

This study supports previous findings that subclover seedling biomass, leaf size and petiole length are a reflection of cotyledon weight/size, which depends on seed weight (Black 1956; Black 1957; Donald 1951; Gladstones 1967). This could be explained by the significance of large cotyledons (i.e. large seeds) that can deliver an initial advantage for growth rates of subsequent seedling which allows individual plants to be superior in terms of capture of light, space and soil resources and subsequent biomass accumulation, including the production of larger leaves and longer petioles (Black 1960; Black 1957; Brougham 1958; Davidson and Donald 1958; Gladstones 1967). However, in present study, early seedling vigour of ssp. yanninicum was irrelevant for tolerance to waterlogging. Palta et al. (2010) also found that vigorous early growth of seedlings is unrelated for tolerance to waterlogging in chickpea. This can be explained as genotypes with lower initial shoot biomass need to improve their growth rates above the soil surface to respond soil waterlogging. As discussed earlier, an increased proportion of aerial organs enables higher oxygen uptake and greater exchange of gases under waterlogging (Colmer 2003; Striker et al. 2005; Striker and Colmer 2017). It also could be a genotype with high initial shoot biomass saves reserves (energy and carbohydrates) for later use, since resources already accumulated in biomass (aerial organs) might be enough to respond waterlogging stress. Striker (2012b) highlighted that plant growth responses under waterlogging do not fully define tolerance to the stress. Little or absence of growth under waterlogging can save reserves and deliver benefits for rapid growth following alleviation of waterlogging stress (Setter and Waters 2003; Striker 2012b). Enkhbat et al (2021) found a high growth of ssp. yanninicum under waterlogging had a negative effect on both shoot and root RGRs at the subsequent recovery stage compared than the two other subclover subspecies with lower growth under waterlogging but had higher recovery than ssp. yanninicum. Further research is, therefore, required to investigate performance of ssp. yanninicum after alleviation of waterlogging stress comparing their growth under waterlogging to evaluate tolerance to waterlogging of ssp. yanninicum.

Relationships of variation for waterlogging tolerance with eco-geographic variables

Waterlogging tolerance of ssp. yanninicum was not correlated with any of geographic coordinates and this can be associated with the restricted distribution of ssp. yanninicum. The natural habitat of ssp. yanninicum is reported to be low altitude coastal areas (often flat meadows) with high mean annual rainfall (> $500 \mathrm{~mm}$ ) and mild winter temperatures (Katznelson 1966; Francis 1976; Ghamkhar et al. 2015). The distribution of ssp. yanninicum in a lower profiles of the landscape (below $1400 \mathrm{~m}$ a.s.l), which tends to collect more water, could be a consequence of ssp. yanninicum to maintain inherent features to confer adaptation to waterlogging than the two other subclover subspecies that can be found in elevation up to $2190 \mathrm{~m}$ a.s.I for ssp. brachycalycinum and $2940 \mathrm{~m}$ a.s.I for ssp. subterraneum (Ghamkhar et al. 2015).

Annual and winter rainfall at the site of origin were highly correlated with seed size and initial seedling growth of ssp. yanninicum. This supports Pecetti and Piano (2002) and Piano et al. (1996), who found that individual seed weight of subclover increases with increasing annual rainfall at the site of origin. As discussed earlier, if seed weight is high, subsequent seedling growth (winter biomass) and associated traits such as cotyledon size/weight, leaf size and petiole length tend to be high. But, waterlogging tolerance of ssp. yanninicum was not correlated with rainfall at the site of origin, which could be associated with their restricted distribution with uniform climatic regions, as discussed earlier. Additionally, warmer temperatures at the collection site favoured waterlogging tolerance in ssp. yanninicum.

Loading [MathJax]/jax/output/CommonHTML/jax.js 


\section{Plant Breeding Implication}

This study has identified promising material for plant breeders as new parents for crossing to enhance waterlogging tolerance and increase the genetic base in this globally important annual legume. The observed results in this study could be different in their natural environments (Villemereuil et al. 2015) due to this experiment being conducted under highly controlled experimental conditions. Environmental factors, such as low temperatures or nutrient deficiencies, are likely to influence plant growth compared to glasshouse conditions. Further studies should be conducted under waterlogged field conditions to validate results delivered from the glasshouse experiment.

This study focused on selection criteria for waterlogging tolerance of ssp. yanninicum on morphological responses, such as shoot and root biomass production, leaf and petiole growth and formation of surface roots. The approach could be enhanced by future research to focus on other key responses to waterlogging mechanisms such as shoot physiological responses, changes in root anatomical and morphological responses.

Finally, this study only assessed growth of ssp. yanninicum under waterlogging. Recovery ability following alleviation of waterlogging stress is crucial for plants to gain shoot biomass and to evaluate tolerance to waterlogging (Striker 2012b), particularly in self-regenerating pastures for seed production (Striker and Colmer 2017). Recovery ability in the three subspecies of subclover studied in Enkhbat et al. (2021b), that both of shoot and root growth after 21 days recovery was lower in ssp. yanninicum than ssp. subterraneum. Response to post-waterlogging stress within genotypes of ssp. yanninicum is, therefore, essential to identify genotypes with better performance after waterlogging.

\section{Declarations}

\section{Acknowledgements}

This research was conducted as part of the Annual Legume Breeding Australia (ALBA) Joint Venture between PGG Wrightson Seeds and UWA. The project is under the International Collaborative Program in Agricultural Sciences between Nagoya University and UWA. G.E. is supported by an Australian Government Research Training Program (RTP) scholarship and a Science Industry PhD Fellowship from the Government of Western Australia. We gratefully acknowledge Robert Creasy, Evonne Walker, Bill Piasini, Elise Robinson and Robert Jeffery for technical help.

\section{References}

Abdi Al, Nichols PGH, Kaur P, Wintle BJ, Erskine W (2020) Morphological diversity within a core collection of subterranean clover (Trifolium subterraneum L.): lessons in pasture adaptation from the wild. PloS One 15: e0223699-e0223699

Armstrong W (1980) Aeration in higher plants. In: Woolhouse HW (ed) Advances in botanical research, vol 7. Elsevier Science \& Technology, pp 225-332

Armstrong W, Healy MT, Lythe S (1983) Oxygen diffusion in pea. II. Oxygen concentrations in the primary pea root apex as affected by growth, the production of laterals and radial oxygen loss. New Phytol 94:549-559

Ashraf M, Mehmood S (1990) Effects of waterlogging on growth and some physiological parameters of four Brassica species. Plant Soil 121:203-209

Bailey-Serres J, Voesenek LACJ (2008) Flooding stress: acclimations and genetic diversity. Annu Rev Plant Biol 59:313-339

Bertholdsson N (2013) Screening for barley waterlogging tolerance in nordic barley cultivars (Hordeum vulgare L.) using chlorophyll fluorescence on hydroponically-grown plants. Agronomy (Basel) 3:376-390

Black J (1960) The significance of petiole length, leaf area, and light interception in competition between strains of subterrranean clover (Trifolium subterraneum L.) grown in swards. Aust J Agric Res 11:277-291

Black JN (1956) The influence of seed size and depth of sowing on pre-emergence and early vegetative growth of subterranean clover (Trifolium subterraneum L.). Crop Pasture Sci 7:98-109

Black JN (1957) The early vegetative growth of three strains of subterranean clover (Trifiolium subterraneum L.) in relation to size of seed Crop Pasture Sci 8:1-14

Booth TH (2018) Why understanding the pioneering and continuing contributions of BIOCLIM to species distribution modelling is important Austral Ecol 43:852-860

Brougham RW (1958) Leaf development in swards of white clover (Trifolium repens L.). N Z J Agric Res 1:707-718

Cannell RQ, Belford RK (1980) Effects of waterlogging at different stages of development on the growth and yield of winter oilseed rape (Brassica napus L.) J Sci Food Agric 31:963-965

Chapman SC, Chakraborty SM, Dreccer MF, Howden SM (2012) Plant adaptation to climate change-opportunities and priorities in breeding. Crop Pasture Sci 63:251-268

Cocks P (1994) Colonization of a South Australian grassland by invading Mediterranean annual and perennial pasture species. Aust J Agric Res 45:1063-1076 Loading [MathJax]/jax/output/CommonHTML/jax.js

Page $13 / 21$ 
Colmer TD (2003) Long-distance transport of gases in plants: a perspective on internal aeration and radial oxygen loss from roots. Plant, Cell Environ 26:17-36 Colmer TD, Greenway H (2011) Ion transport in seminal and adventitious roots of cereals during $\mathrm{O}_{2}$ deficiency. J Exp Bot 62:39-57

Colmer TD, Voesenek LACJ (2009) Flooding tolerance: suites of plant traits in variable environments. Funct Plant Biol 36:665-681

Craig A (1992) Pasture production of two cultivars of Trifolium subterraneum at Kybybolite, South Australia. Aust J Exp Agric 32:611-617

Davidson J, Donald C (1958) The growth of swards of subterranean clover with particular reference to leaf area. Aust J Agric Res 9:53-72

Davies CL, Turner DW, Dracup M (2000) Yellow lupin (Lupinus luteus) tolerates waterlogging better than narrow-leafed lupin (L. angustifolius). I. Shoot and root growth in a controlled environment. Aust J Agric Res 51:701-709

Devitt A, Francis C (1972) The effect of waterlogging on the mineral nutrient content of "Trifolium subterraneum". Aust J Exp Agric 12:614

Donald C (1951) Competition among pasture plants. I. Intraspecific competition among annual pasture plants. Aust J Agric Res 2:355-376

Enkhbat G, Nichols PGH, Foster KJ, Ryan MH, Inukai Y, Erskine W (2021a) Diversity for morphological traits, flowering time and leaf isoflavone content among ecotypes of Trifolium subterraneum L. ssp. yanninicum and their relationships with site of origin Crop Pasture Sci (in press)

Enkhbat G et al. (2021b) Large variation in waterlogging tolerance and recovery among the three subspecies of Trifolium subterranean L. is related to root and shoot responses. Plant Soil 464:467-487

Erskine W, Adham Y, Holly L (1989) Geographic distribution of variation in quantitative traits in a world lentil collection. Euphytica 43:97-103

Erskine W, Tufail M, Russell A, Tyagi MC, Rahman MM, Saxena MC (1994) Current and future strategies in breeding lentil for resistance to biotic and abiotic stresses. Euphytica 73:127-135

Falconer DS (1989) Introduction to quantitative genetics. 3 edn. Longman, Scintific \& Technical Burnt Mill, Harlow, Essex, England

Francis C, Devitt A (1969) The effect of waterlogging on the growth and isoflavone concentration of Trifolium subterraneum L. Aust J Agric Res 20:819-825

Francis CM (1976) Observations on the ecology of subterranean clover in Greece and Crete: a report based on a seed collection tour 1976. Western Australian Dept. of Agriculture, Perth, WA

Francis CM, Devitt AC, Steele P (1974) Influence of Flooding on the Alcohol Dehydrogenase Activity of Roots of Trifolium subterraneum L. Funct Plant Biol 1:913

Gardner WK, Flood RG (1993) Less waterlogging damage with long season wheats. Cereal Research Communications 21:337-343

Ghamkhar K, Nichols PGH, Erskine W, Snowball R, Murillo M, Appels R, Ryan MH (2015) Hotspots and gaps in the world collection of subterranean clover (Trifolium subterraneum L.). J Agric Sci 153:1069-1083

Ghamkhar K, Snowball R, Bennett SJ (2007) Ecogeographical studies identify diversity and potential gaps in the largest germplasm collection of bladder clover (Trifolium spumosum L.). Aust J Agric Res 58:728-738

Gibberd MR, Cocks PS (1997) Effect of waterlogging and soil pH on the micro-distribution of naturalised annual legumes. Aust J Agric Res 48:223-230

Gibberd MR, Gray JD, Cocks PS, Colmer TD (2001) Waterlogging tolerance among a diverse range of Trifolium accessions is related to root porosity, lateral root formation and 'aerotropic rooting'. Ann Bot 88:579-589

Gladstones J (1967) Naturalized subterranean clover strains in Western Australia: A preliminary agronomic examination. Aust J Agric Res 18:713-731

Hamilton G, Bakker D, Houlebrook D, Spann C (2000) Raised beds prevent waterlogging and increase productivity. Aust J Soil Res 43:575-585

Herzog M, Striker GG, Colmer TD, Pedersen O (2016) Mechanisms of waterlogging tolerance in wheat -a review of root and shoot physiology. Plant, Cell Environ 39:1068-1086

Hijmans RJ, Cameron SE, Parra JL, Jones PG, Jarvis A (2005) Very high resolution interpolated climate surfaces for global land areas. Int J Climatol 25:19651978

Hill MJ (1996) Defining the white clover zone in eastern mainland Australia using a model and a geographic information system. Ecol Model 86:245-252 Huang Bingru B, Johnson JW, Nesmith S, Bridges DC (1994) Growth, physiological and anatomical responses of two wheat genotypes to waterlogging and nutrient supply. J Exp Bot 45:193-202

Hunt R (1982) Plant growth curves: the functional approach to plant growth analysis. Edward Arnold, London 
Jarvis A, Ramirez J, Anderson B, Leibing C, Aggarwal P (2010) Scenarios of climate change within the context of agriculture. In: Reynolds MP (ed) Climate change and crop production. CABI, Wallingford

Justin SHFW, Armstrong W (1987) The anatomical characteristics of roots and plant response to soil flooding. New Phytol 106:465-495

Katznelson J, Morley FHW (1965) A taxonomic revison of sect. Calycomorphum of the genus Trifolium. I. The geocarpic species. Isr J Bot 14:112-134

Khazaei H, Street K, Bari A, Mackay M, Stoddard FL (2013) The FIGS (focused identification of germplasm strategy) approach identifies traits related to drought adaptation in Vicia faba genetic resources. PloS one 8:e63107-e63107

Kidd DR, Di Bella CE, Kotula L, Colmer TD, Ryan MH, Striker GG (2020) Defining the waterlogging tolerance of Ornithopus spp. for the temperate pasture zone of southern Australia. Crop Pasture Sci 71:506-516

Malik Al, Ailewe TI, Erskine W (2015) Tolerance of three grain legume species to transient waterlogging. AoB Plants 7:plv040

Malik Al, Colmer TD, Lambers H, Setter TL, Schortemeyer M (2002) Short-term waterlogging has long-term effects on the growth and physiology of wheat. New Phytol 153:225-236

Mano Y, Omori F, Takamizo T, Kindiger B, Bird R, Loaisiga C (2006) Variation for root aerenchyma formation in flooded and non-flooded maize and teosinte seedlings. Plant Soil 281:269-279

Marschner H (1995) Mineral nutrition of higher plants. 2nd ed. edn. Academic, London

Marshall T, Millington A (1967) Flooding tolerance of some Western Australian pasture legumes. Aust J Exp Agric 7:367-371

McDonald GK, Gardner WK (1987) Effect of waterlogging on the grain yield response of wheat to sowing date in south-western Victoria [cultivars]. Aust J Exp Agric 27:661-670

Nakai A, Yurugi Y, Kisanuki H (2009) Growth responses of Salix gracilistyla cuttings to a range of substrate moisture and oxygen availability. Ecol Res 24

Nichols PGH, Collins WJ, Barbetti MJ (1996) Registered cultivars of subterranean clover -their characteristics, origin and identification. Chief executive officer, Western Australia

Nichols PGH, Foster KJ, Piano E, Pecetti L, Kaur P, Ghamkhar K, Collins WJ (2013) Genetic improvement of subterranean clover (Trifolium subterraneum L.). 1. Germplasm, traits and future prospects. Crop Pasture Sci 64:312-346

Nichols PGH et al. (2007) New annual and short-lived perennial pasture legumes for Australian agriculture - 15 years of revolution. Field Crops Res 104:10-23

Oram RN (1989) Register of Australian herbage plant cultivars. 3rd ed. / compiled by R.N. Oram. edn. Australian Herbage Plant Registration Authority, Division of Plant Industry, CSIRO, Melbourne

Palta JA, Ganjeali A, Turner NC, Siddique KHM (2010) Effects of transient subsurface waterlogging on root growth, plant biomass and yield of chickpea Agric Water Manage 97:1469-1476

Pang J, Zhou M, Mendham N, Shaballa S (2004) Growth and physiological responses of six barley genotypes to waterlogging and subsequent recovery. Aust J Agric Res 55:895-895

PBR (2021) Plant Breeders Rights database. Commonwealth Government of Australia. https://www.ipaustralia.gov.au/plant-breeders-rights.

Peak JW, Morley FHW (1973) Comparison of introduced lines of Trifolium subterraneum subsp. yanninicum with cultivars of T. subterraneum. 3 Irrigated and dryland sward trials at Canberra, Australian Capital Territory vol Field station record 12. Division of Plant Industry, CSIRO (Australia)

Pecetti L, Piano E (2002) Variation of morphological and adaptive traits in subterranean clover populations from Sardinia (Italy). Genet Resour Crop Evol 49:189-197

Piano E (1984) Preliminary observations on the structure and variability of Sardinian populations of subterranean clover. Genet Agr 38:75-90

Piano E, Pecetti L, Carroni AM (1996) Climatic adaptation in subterranean clover populations. Euphytica 92:39-44

Ponnamperuma FN (1984) Effects of flooding on soils. In: Kozlowski TT (ed) Flooding and plant growth. Academic Press, San Diego, pp 9-45

Real D, Warden J, Sandral GA, Colmer TD (2008) Waterlogging tolerance and recovery of 10 Lotus species. Aust J Exp Agric 48:480-487

Reed K, Schroder P, Eales J, McDonald R, Chin J (1985) Comparative productivity of Trifolium subterraneum and T. yanninicum in south-western Victoria. Aust J Exp Agric 25:351-361

Rogers ME et al. (2009) The influence of $\mathrm{NaCl}$ salinity and hypoxia on aspects of growth in Trifolium species. Crop Pasture Sci 60:71-82

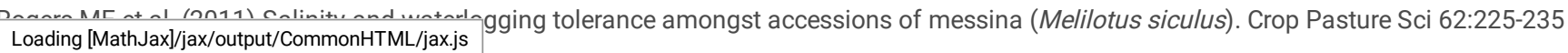

Page $15 / 21$ 
Rogers ME, West DW (1993) The effects of rootzone salinity and hypoxia on shoot and root growth in Trifolium species. Ann Bot 72:503-509

Sandral GA, Peoples MB, Wilson BCD, Taylor JN, Rodham CA (2003) Growth, seed set and nitrogen fixation of 28 annual legume species on 3 Vertosol soils in southern New South Wales. Anim Prod Sci 43:1101-1115

Setter TL, Burgess P, Kuo J (1999) Genetic diversity of barley and wheat for waterlogging tolerance in Western Australia. In: Proceedings of the 9th Australian Barley Technical Symposium, Melbourne, Australia

Setter TL, Waters I (2003) Review of prospects for germplasm improvement for waterlogging tolerance in wheat, barley and oats. Plant Soil 253:1-34

Siddique KHM, Brinsmead RB, Knight R, Knights EJ, Paull JG, Rose IA (2000) Adaptation of chickpea (Cicer arietinum L.) and faba bean (Vicia faba L.) to Australia. In: Knight R (ed) Linking Research and Marketing Opportunities for Pulses in the 21st Century: Proceedings of the Third International Food Legumes Research Conference. Springer Netherlands, Dordrecht, pp 289-303

Smethurst CF, Shabala S (2003) Screening methods for waterlogging tolerance in lucerne: comparative analysis of waterlogging effects on chlorophyll fluorescence, photosynthesis, biomass and chlorophyll content. Funct Plant Biol 30:335-343

Solaiman Z, Colmer TD, Loss SP, Thomson BD, Siddique KHM (2007) Growth responses of cool-season grain legumes to transient waterlogging. Aust J Agric Res 58:406-412

Stoddard FL, Balko C, Erskine W, Khan HR, Link W, Sarker A (2006) Screening techniques and sources of resistance to abiotic stresses in cool-season food legumes. Euphytica 147:167-186

Striker G (2012a) Flooding stress on plants: anatomical, morphological and physiological responses. In: Mworia JK (ed) Botany. IntechOpen

Striker G, Insausti P, Grimoldi A, Ploschuk E, Vasellati V (2005) Physiological and anatomical basis of differential tolerance to soil flooding of Lotus corniculatus L. and Lotus glaber Mill. Plant Soil 276:301-311

Striker GG (2012b) Time is on our side: the importance of considering a recovery period when assessing flooding tolerance in plants. Ecol Res $27: 983-987$

Striker GG, Colmer TD (2016) Flooding tolerance of forage legumes Journal of Experimental Botany 68:1851-1872

Striker GG, Colmer TD (2017) Flooding tolerance of forage legumes. J Exp Bot 68:1851-1872

Striker GG, Teakle NL, Colmer TD, Barrett-Lennard EG (2015) Growth responses of Melilotus siculus accessions to combined salinity and root-zone hypoxia are correlated with differences in tissue ion concentrations and not differences in root aeration. Environ Exp Bot 109:89

Sultana R et al. (2013) Waterlogging tolerance in pigeonpea (Cajanus cajan (L.) Millsp.): genotypic variability and identification of tolerant genotypes. J Agri Sci 151:659-671

Talbot RJ, Etherington JR, Bryant JA (1987) Comparative studies of plant growth and distribution in relation to waterlogging. XII. Growth, photosynthetic capacity and metal ion uptake in Salix caprea and S. cinerea ssp. Oleifolia. New Phytol 105:563-574

Teakle NL, Bowman S, Barrett-Lennard EG, Real D, Colmer TD (2012) Comparisons of annual pasture legumes in growth, ion regulation and root porosity demonstrate that Melilotus siculus has exceptional tolerance to combinations of salinity and waterlogging. Environ Exp Bot 77:175-184

Tennant D, Scholz G, Dixon J, Purdie B (1992) Physical and chemical characteristics of duplex soils and their distribution in the south-west of Western Australia. Aust J Exp Agric 32:827-843

Trevor HB, Henry AN, John RB, Michael FH (2014) Bioclim: the first species distribution modelling package, its early applications and relevance to most current MaxEnt studies Diversity \& Distributions 20:1-9

Villemereuil PD, Gaggiotti OE, Mouterde M, Till-Bottraud I (2015) Common garden experiments in the genomic era: new perspectives and opportunities. Heredity $116: 249$

Voesenek LACJ, Armstrong W, BÖGemann GM, McDonald MP, Colmer TD (1999) A lack of aerenchyma and high rates of radial oxygen loss from the root base contribute to the waterlogging intolerance of Brassica napus Aust J Plant Physiol 26:87-93

Voesenek LACJ, Sasidharan R (2013) Ethylene- and oxygen signalling-drive plant survival during flooding. Plant Biol 15:426-435

Williams R, Evans L, Ludwig L (1964) Estimation of leaf area for clover and lucerne. Aust J Agric Res 15:231-233 doi:

Yamauchi T, Colmer TD, Pedersen O, Nakazono M (2018) Regulation of root traits for internal aeration and tolerance to soil waterlogging-flooding stress. Plant Physiol 176:1118-1130

\section{Figures}




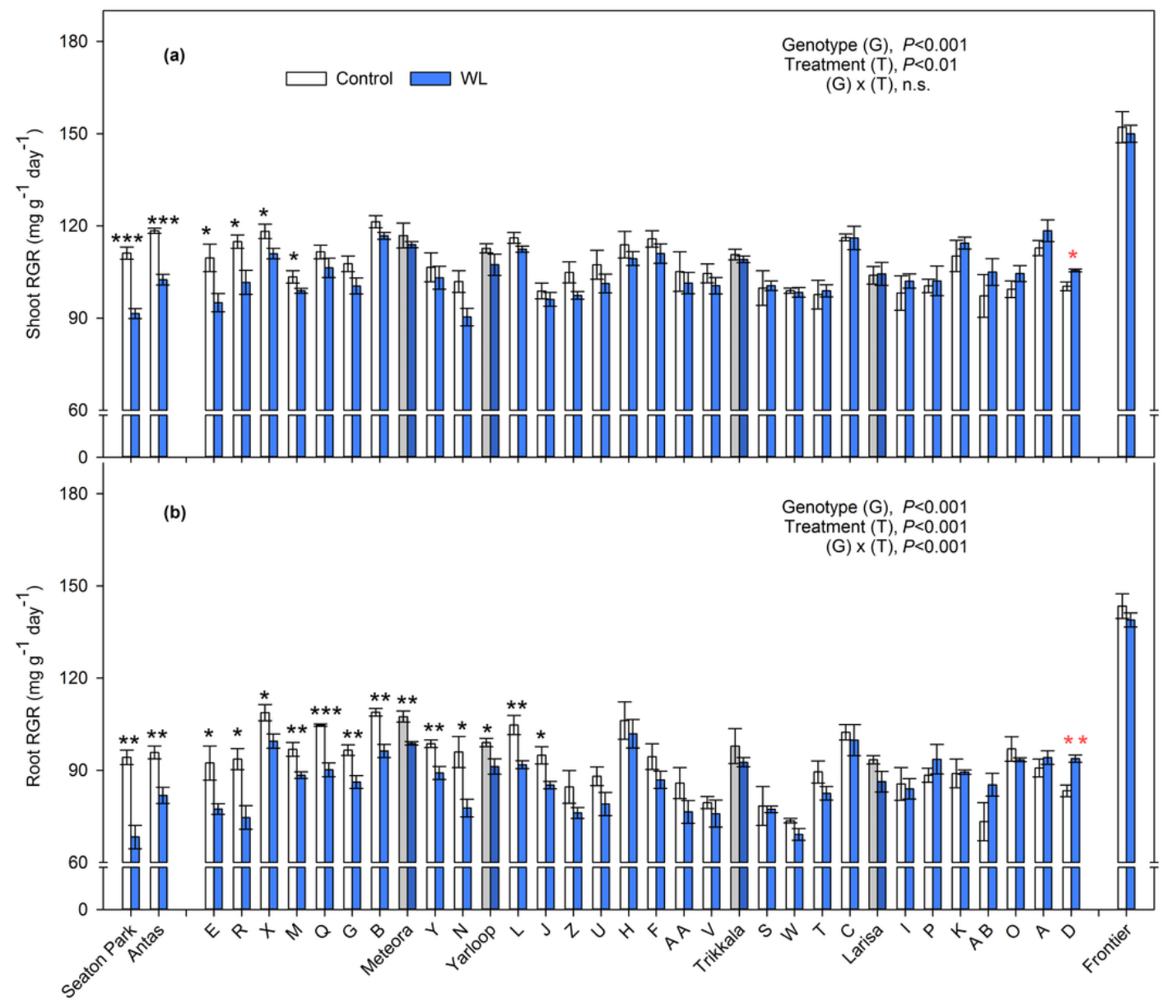

\section{Figure 1}

Relative growth rates (RGR) of (a) shoot and (b) root for $32 \mathrm{ssp}$. yanninicum genotypes, consisting of 4 cultivars (hatched) and 28 ecotypes, and ssp. brachycalycinum cv. Antas, ssp. subterraneum cv. Seaton Park and T. michelianum cv. Frontier after 28 days of treatment (mean $\pm \mathrm{SE} n=4$ ). Treatments were imposed after 21 days of growth: free-drained (control) and waterlogged (WL, water level kept $10 \mathrm{~mm}$ above the soil surface). Results of two-way ANOVA are given in each panel. The single cultivars of ssp. brachycalycinum, ssp. subterraneum and T. michelianium are not included in the statistical analyses. The significant differences $\left(P<0.05\right.$; Fisher LSD test) between control and waterlogged treatments of each genotype are shown: ${ }^{*} P<0.05 ; * \star P<0.01 ; * \star \star P<0.001$ (black indicates the control treatment was higher and red indicates that the waterlogged treatment was higher) 


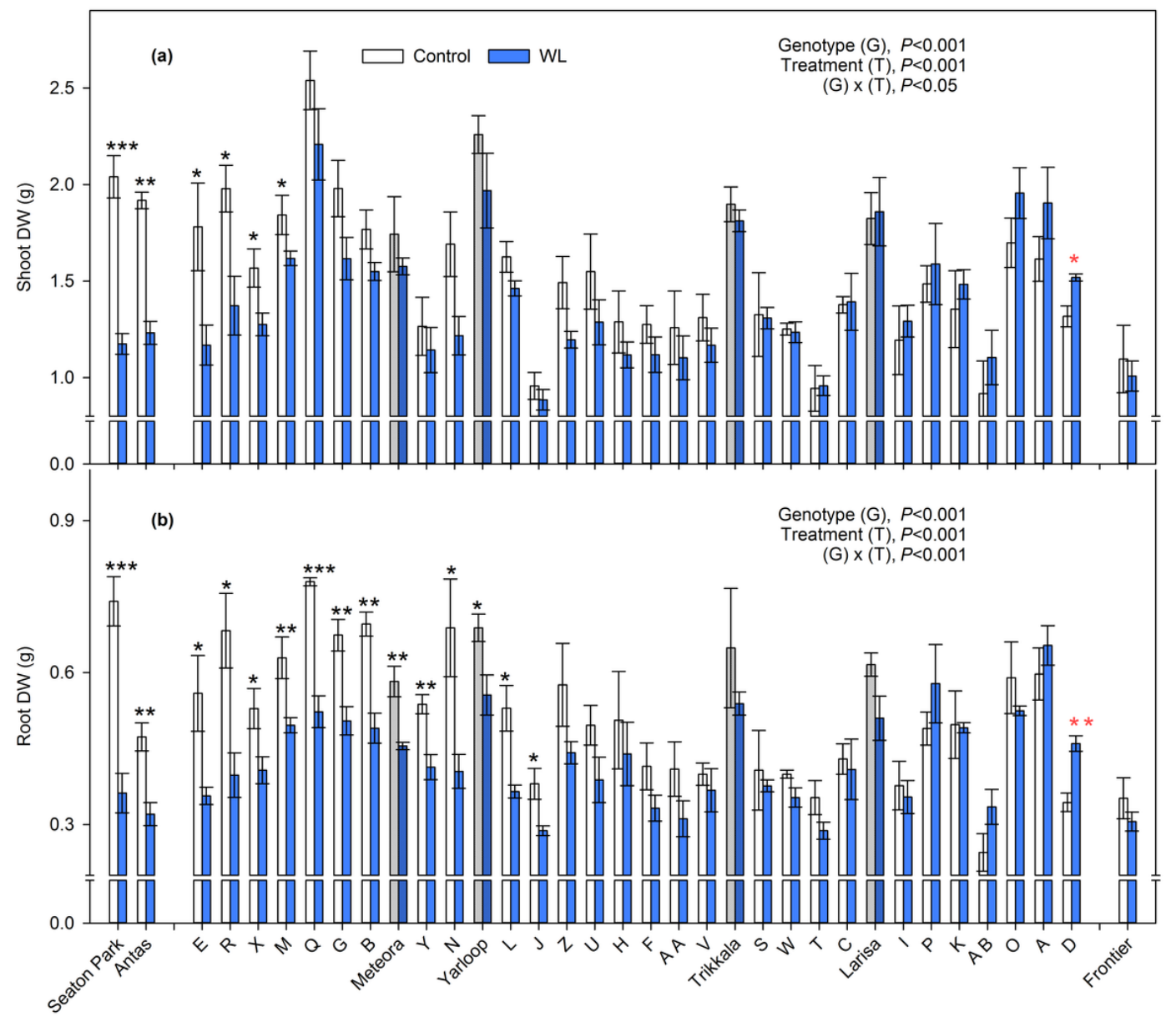

Figure 2

Dry weights (DW) of (a) shoot and (b) root for $32 \mathrm{ssp}$. yanninicum genotypes, consisting of 4 cultivars (hatched) and 28 ecotypes, and ssp. subterraneum cv. Seaton Park, ssp. brachycalycinum cv. Antas and T. michelianum cv. Frontier after 28 days of treatment (mean \pm SE $n=4)$. Treatments were imposed after 21 days of growth: free-drained (control) and waterlogged (WL, water level kept $10 \mathrm{~mm}$ above the soil surface). Results of two-way ANOVA are given in each panel. The single cultivars of ssp. brachycalycinum, ssp. subterraneum and T. michelianium are not included in the statistical analyses. The significant differences $\left(P<0.05\right.$; Fisher LSD test) between control and waterlogged treatments of each genotype are shown: ${ }^{*} P<0.05$; ${ }^{* *} P<0.01$; ${ }^{* * *} P<0.001$ (black indicates the control treatment was higher and red indicates that the waterlogged treatment was higher) 


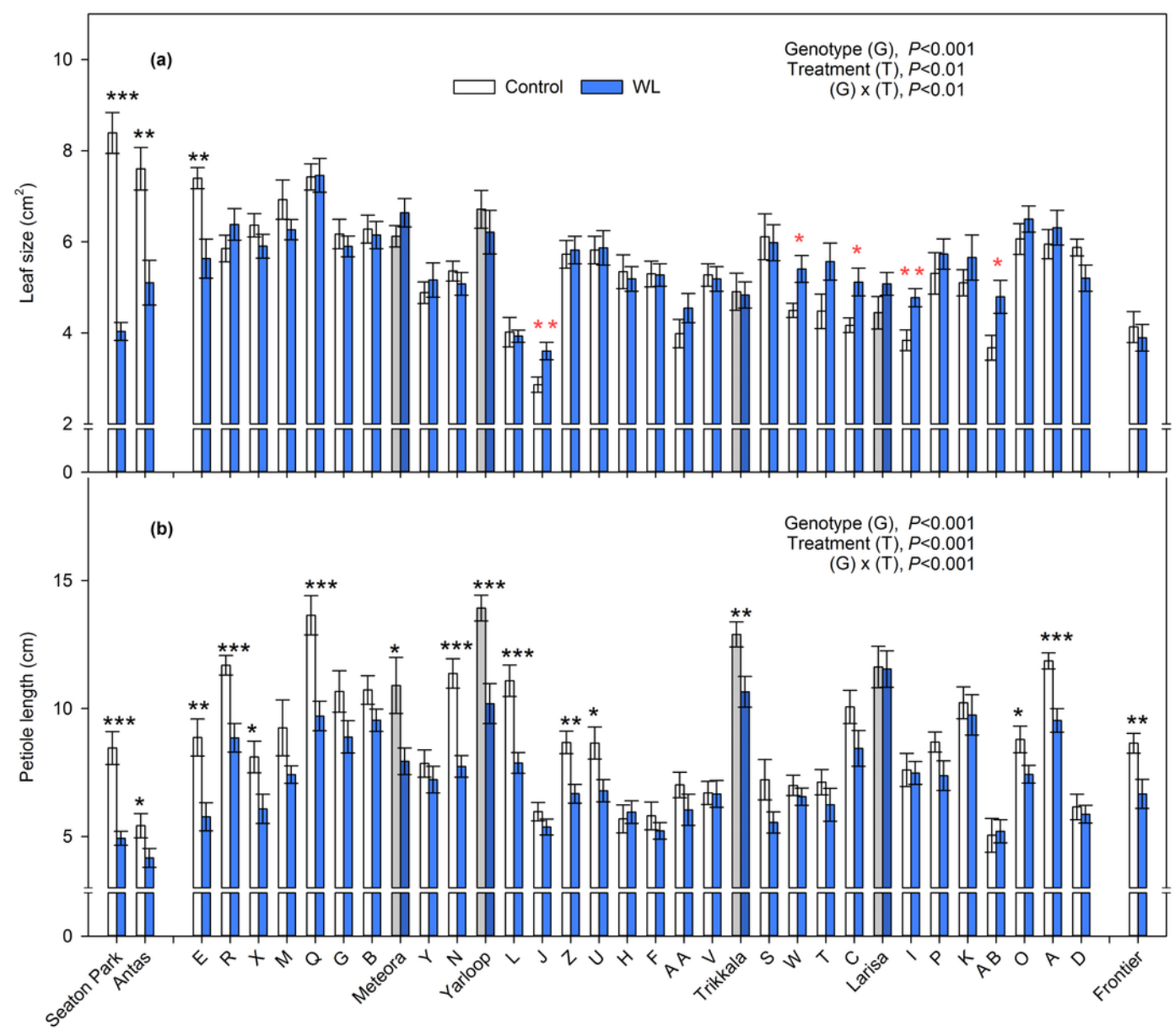

Figure 3

(a) leaf size and (b) petiole length for $32 \mathrm{ssp}$. yanninicum genotypes, consisting of 4 cultivars (hatched) and 28 ecotypes, and ssp. brachycalycinum cv. Antas, ssp. subterraneum cv. Seaton Park and T. michelianum cv. Frontier after 28 days of treatment (mean \pm SE $n=4)$. Treatments were imposed after 21 days of growth: free-drained (control) and waterlogged (WL, water level kept $10 \mathrm{~mm}$ above the soil surface). Results of two-way ANOVA are given in each panel. The single cultivars of ssp. brachycalycinum, ssp. subterraneum and T. michelianium are not included in the statistical analyses. The significant differences $(P<$ 0.05 ; Fisher LSD test) between control and waterlogged treatments of each genotype are shown: ${ }^{*}<<0.05$; ${ }^{*} \mathrm{P}<0.01$; ${ }^{*} \mathrm{P}<0.001$ (black indicates the control treatment was higher and red indicates that the waterlogged treatment was higher). Note the $y$-axis scale change in the panels 


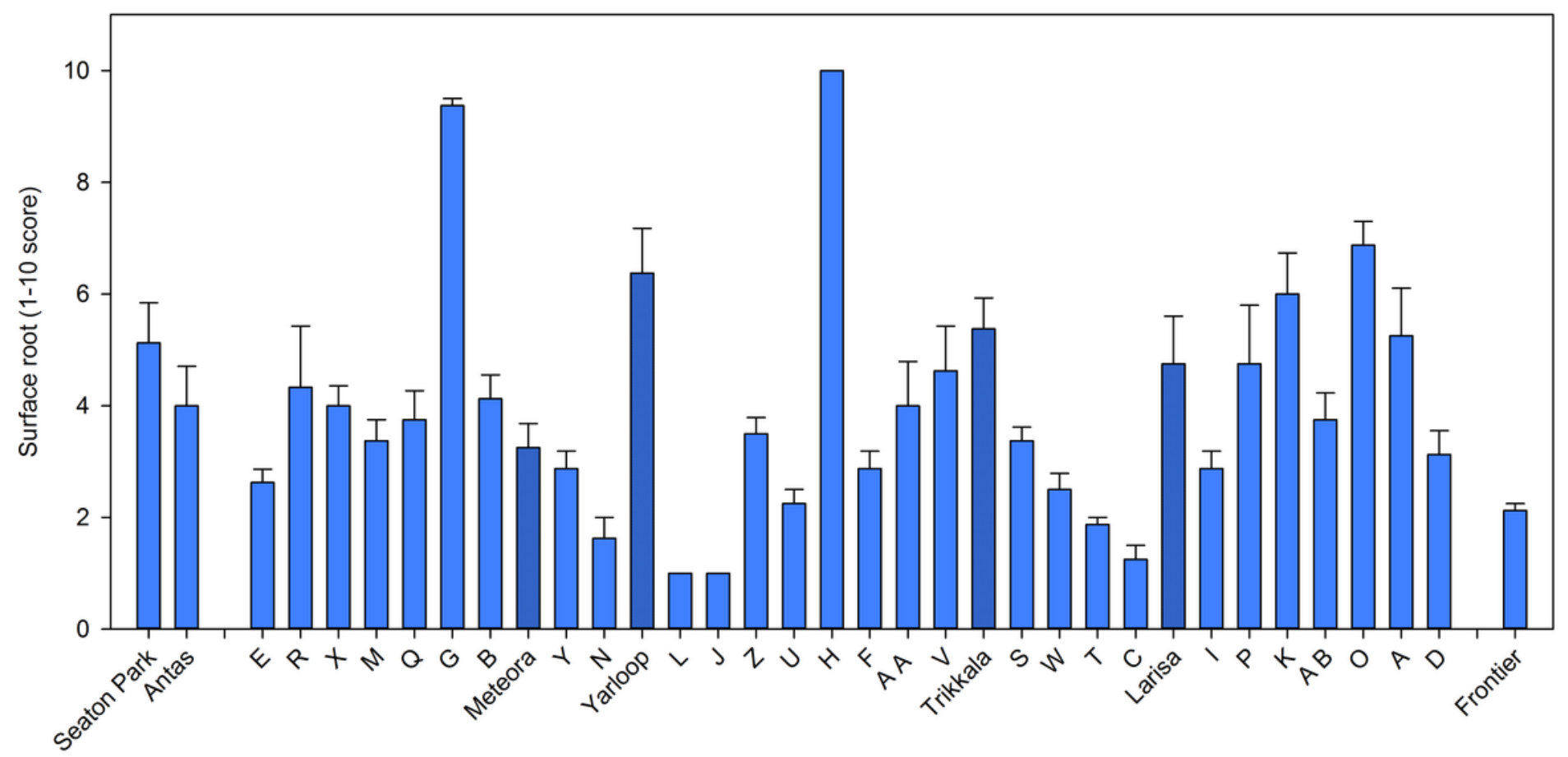

Figure 4

Surface root proliferation after 28 days of waterlogging for $32 \mathrm{ssp}$. yanninicum genotypes, consisting of 4 cultivars (hatched) and 28 ecotypes, and ssp. brachycalycinum cv. Antas, ssp. subterraneum cv. Seaton Park and T. michelianum cv. Frontier grown under waterlogging (mean $\pm \mathrm{SE} n=4)$. The waterlogging treatment was imposed after 21 days of growth (water level kept $10 \mathrm{~mm}$ above the soil surface). Surface roots were scored on a 1-10 scale (where 1 is the lowest growth and 10 is the most vigorous growth)

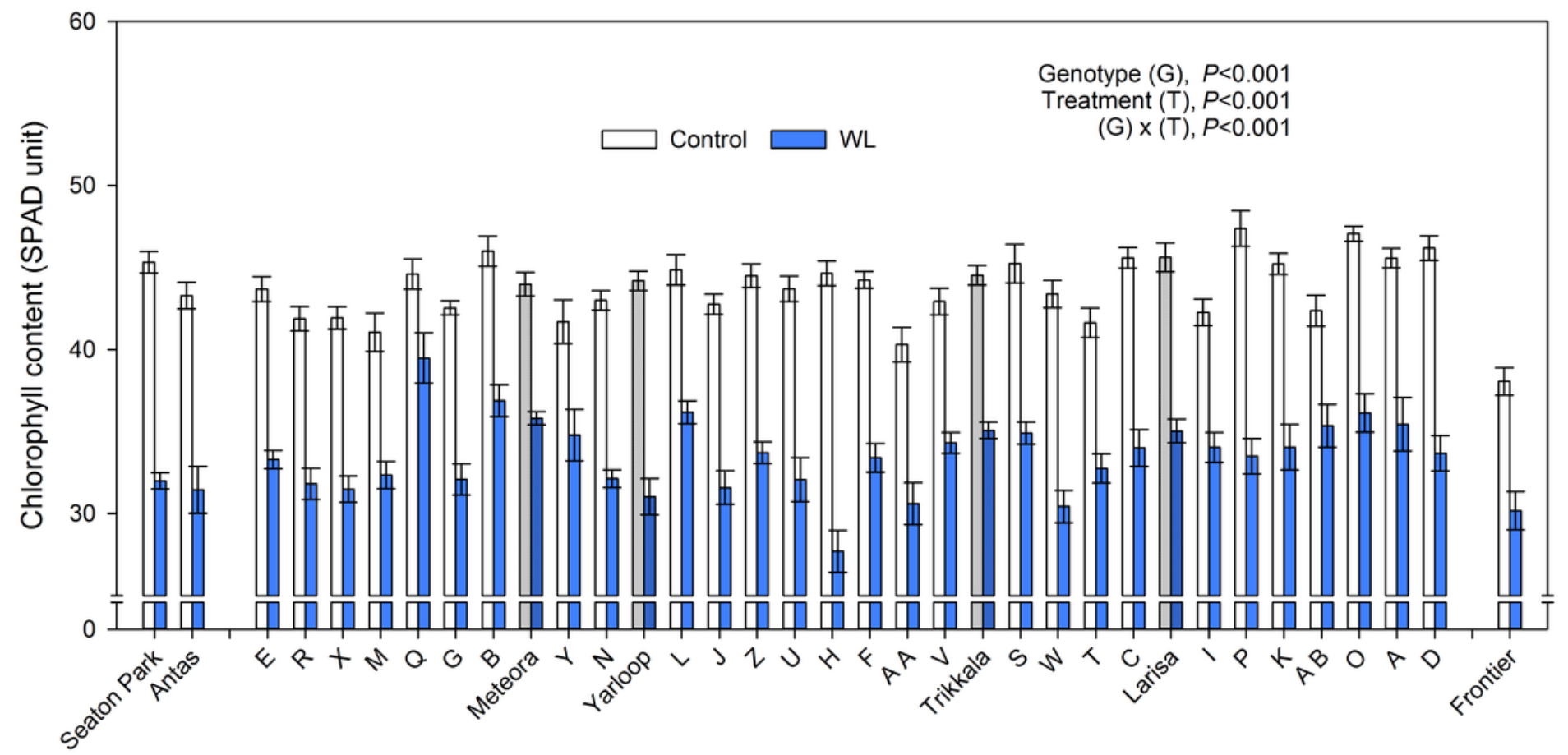


Figure 5

Chlorophyll content for $32 \mathrm{ssp}$. yanninicum genotypes, consisting of 4 cultivars (hatched) and 28 ecotypes, and ssp. brachycalycinum cv. Antas, ssp. subterraneum cv. Seaton Park and T. michelianum cv. Frontier after 28 days of treatment (mean \pm SE $n=4)$. Treatments were imposed after 21 days of growth: free-drained (control) and waterlogged (WL, water level kept $10 \mathrm{~mm}$ above the soil surface). Results of two-way ANOVA are given in the panel. The single cultivars of ssp. brachycalycinum, ssp. subterraneum and T. michelianium are not included in the statistical analyses

\section{Supplementary Files}

This is a list of supplementary files associated with this preprint. Click to download.

- Enkhbatetal.supplementarydata.xlsx 